\title{
The response of a gravel-bed river planform configuration to flow variations and bed reworking: a modelling study
}

\begin{tabular}{|r|l|}
\hline Journal: & Hydrological Processes \\
\hline Manuscript ID: & HYP-14-1037.R2 \\
\hline Wiley - Manuscript type: & Research Article \\
\hline Complete List of Authors: & $\begin{array}{l}\text { Kaless, Gabriel; Universidad Nacional de la Patagonia San Juan Bosco, } \\
\text { Department Civil and Hydraulic Engineering; University of Padova, } \\
\text { Department of Land, Environment, Agriculture and Forestry } \\
\text { Mao, Luca; Pontificia Universidad Católica de Chile, Department of } \\
\text { Ecosystems and Environment } \\
\text { Moretto, Johnny; University of Padova, Department of Land, Environment, } \\
\text { Agriculture and Forestry } \\
\text { Picco, Lorenzo; University of Padova, Department of Land, Environment, } \\
\text { Agriculture and Forestry } \\
\text { Lenzi, Mario Aristide; University of Padova, Department of Land, } \\
\text { Environment, Agriculture and Forestry }\end{array}$ \\
\hline Keywords: & $\begin{array}{l}\text { Gravel-bed rivers, 2D-depth averaged model, hydrodynamic- } \\
\text { sedimentological model, bed load, armour layer, bed evolution }\end{array}$ \\
\hline
\end{tabular}




\title{
The response of a gravel-bed river planform configuration to flow variations and bed reworking: a modelling study
}

\author{
Gabriel Kaless ${ }^{1,2}$, Luca Mao ${ }^{3}$, Johnny Moretto ${ }^{1}$, Lorenzo Picco ${ }^{1}$, Mario A. Lenzi ${ }^{1}$ \\ ${ }^{1}$ Department of Land, Environment, Agriculture and Forestry; University of Padova, Italy. \\ 2 Department of Civil and Hydraulic Engineering; Universidad Nacional de la Patagonia "San Juan \\ Bosco", Argentina. \\ ${ }^{3}$ Department of Ecosystems and Environment; Pontificia Universidad Católica de Chile, Santiago, \\ Chile.
}

Correspondence to: Gabriel Kaless, Universidad Nacional de la Patagonia "San Juan Bosco", Belgrano y 9 de Julio, (9100), Trelew, Pcia. del Chubut, Argentina. Tel/Fax +54-280-4428403 Email: gkaless@ing.unp.edu.ar

\section{Abstract}

A 2D depth averaged model has been developed for simulating water flow, sediment transport and morphological changes in gravel bed rivers. The model was validated with a series of laboratory experiments and then applied to the Nove reach of the Brenta River (Northern Italy) to assess its bed material transport, interpret channel response to a series of intensive flood events (R.I. $\approx 10$ years), and provide a possible evolutionary scenario for the medium term. The study reach is $1400 \mathrm{~m}$ long with a mean slope of $0.0039 \mathrm{~m} \mathrm{~m}^{-1}$. High resolution digital terrain models were produced combining LiDAR data with colour bathymetry techniques. Extensive field sedimentological surveys were also conducted for surface and subsurface material. Data were uploaded in the model and the passage of two consecutive high intensity floods was simulated. The model was run under several hypotheses of sediment supply: one considering substantial equilibrium between sediment input and transport capacity, and the others reducing the sediment supply. The sediment supply was then calibrated comparing channel morphological changes as observed in the field and calculated by the model. Annual bed material transport was assessed and compared with other techniques. Low-frequency floods (R.I. $\approx 1.5$ years) are expected to produce negligible changes in the channel while high floods may erode banks rather than further incising the channel bed. Location and distribution of erosion and deposition areas within the Nove reach were predicted with acceptable biases stemming from imperfections of the model and the specified initial, boundary and forcing conditions. A medium-term evolutionary scenario simulation underlined the different response to and impact of a consecutive sequence of floods.

Key words: gravel-bed rivers, 2D-depth-averaged model, hydrodynamic-sedimentological model, bed load, armour layer, bed evolution. 


\section{Introduction}

Many gravel-bed rivers in Italy have been disturbed by human interventions over the last decades (Surian and Rinaldi, 2003). The recent narrowing and incising trends of the Brenta River (Northern Italy) have been analyzed by means of aerial photographs (Moretto et al., 2014b). In other cases, such as the Piave River (Northern Italy), the availability of historical documents allowed the complete reconstruction of a chronology of changes over the last 200 years (Comiti et al., 2011). Basin works such as reforestation, building of check-dams along tributaries, and the construction of major reservoirs for electricity generation have severely reduced the sediment supply to lowland gravel-bed rivers. Local in-channel activities such as gravel mining and longitudinal bank protections have also increased the sediment deficit (Surian and Rinaldi, 2003). Nowadays, it is widely recognized that a change in sediment supply can be the key factor in determining channel adjustments in many gravel-bed rivers (e.g. Rinaldi et al., 2005; Comiti et al., 2011). Hence, in most cases management strategies have concentrated on influencing sediment supply to restore river systems by enhancing channel dynamics.

Recent studies have been performed on the Danube River (Austria), where bedload was measured by direct techniques (Liedermann et al., 2010a, 2010b, 2013; Tritthart et al., 2011b). Other examples of direct measurement techniques used on gravel-bed rivers are reported in the literature (Habersack, 2001; Rennie and Millar, 2004; Lamarre et al., 2005, 2008; Allan et al., 2006; Habersack et al., 2008, 2013; Liebault et al., 2009; Tritthart et al., 2011b). However, sediment transport is not usually directly measured in large gravel-bed rivers because it can be a dangerous and expensive task, so indirect or morphological strategies are used instead (e.g. Gray et al., 2010). So far, cross sections in Italian gravel-bed rivers have been surveyed and compared along the reaches of Brenta River (Surian and Cisotto, 2007) and Piave River (Comiti et al., 2011), involving standard GPS procedures. Recently, the combined use of laser imaging detection and ranging (LiDAR) data and elevation reconstruction by colour bathymetry techniques has produced high resolution digital terrain models (DTMs) which allow detailed studies at the reach scale (Moretto et al., 2014a).

If field data on sediment transport are not available and difficult to gather, an alternative for assessing sediment dynamics in a gravel-bed river is the use of numerical models. The selection of the appropriate model requires a previous definition of the scale of reference, i.e., the length of the study reach. Three types of model are available: 1D models for the analysis of water depth, longitudinal flow velocities and shear stress, and sediment transport capacity, over tens of kilometers; 2D models, best used on shorter reaches for the analysis of specific morphological units; and 3D models at very specific sites such as bridges, embankments, and rip-raps. Restoration programs in Europe have made use of these techniques to support river modeling focused on assessing the potential impacts of different river management strategies (Habersack and Piégay, 2006; Formann et al., 2007). These models are based on the Saint-Venant equations or the Reynold's equation that describe the flow in 1D models and 2D-3D models, respectively. As an alternative, reduced-complexity numerical models have recently been used on gravel-bed rivers. For example, Ziliani and Surian (2012) applied a cellular automaton model for interpreting past changes in the Tagliamento River and to assess possible evolutionary trajectories according to different flow regime scenarios. 
Several 2D models have been developed over the last years for explaining and predicting the shape of a river. Some were created to reproduce the complex flow in meandering rivers (Wu et al., 2000; Ferguson et al., 2003; Abad et al., 2008). The flow of water in meandering rivers is highly disturbed by channel sinuosity that induces secondary currents (Rozovskii, 1961). Sediment is transported both in suspension and as bed load and comprises fine sizes, i.e., sand. In addition, bank failure models have to consider material cohesion due to the presence of silt and clay (Darby et al., 2002).

Gravel-bed rivers have several features that differentiate them from sand-bed rivers: both bed and banks are composed of non-cohesive material (mixture of sand, gravel and cobbles, although some cohesion can be provided by vegetation roots), the aspect ratio (width/depth) is higher because channels are wider and shallower; bed load transport is responsible for shaping the channel, material in suspension is negligible for channel change (Leopold, 1992), and the bed is usually armoured, which regulates the interaction between bed surface and sediment transport (Parker and Klingeman, 1982). These features impose new and different challenges for modeling. The last years have also witnessed the production of numerical models that consider some of the aforementioned features. For instance, Nataga et al. (2000) developed a depth-averaged shallow water model including a sediment transport model (with only one grain size) and a bank failure model for gravel-bed rivers. Jang and Shimizu (2005) and Garcia-Martinez et al. (2006) later developed models for wide channels using Meyer-Peter and Müller's sediment transport formula for uniform material. Li and Millar (2007) extended the Mike $21 \mathrm{C}$ model implementing Parker's (1990) sediment transport model for mixtures. Recently, the river simulation model RSim-3D (Tritthart and Gutknecht, 2007a), which solves the 3D Reynolds-averaged Navier Stokes equations using the Finite Volume Method (FVM) on a mesh consisting of arbitrarily shaped polyhedra, was applied to the Danube River (Tritthart and Gutknecht, 2007b; Tritthart et al., 2009) including nonuniform sediment transport (Tritthart et al., 2011a, 2011b).

This paper presents a field case application of the 2D-depth averaged hydrodynamic and sedimentological model designed and developed to assess morphological planform changes and estimate bed material transport associated with flood events in gravel bed rivers. The $2 \mathrm{D}$ model is tested against a series of laboratory runs and then used with a high resolution digital terrain model (DTM) of a reach of the Brenta River with the aims of: a) assessing bed material transport and interpretation of channel planform response to a series of intensive and consecutive flood events (R.I. $\approx 10$ years) that occurred in 2010 ; b) providing a possible evolutionary scenario of the Nove reach of the Brenta River in the medium term.

\section{2D hydrodynamic and sedimentological model}

\subsection{Hydraulic model}

STREMR constituted the starting point for the development of the Licanleufú 2D model (Kaless, 2013; Kaless et al., 2013). STREMR was developed by Robert Bernard at the Waterways Experiment Station of the US Army Corps of Engineers (Bernard, 1993). The model resolves the depth-averaged Reynolds' equations including the standard $k-\varepsilon$ model for turbulence closure. Several changes have been introduced in the original STREMR scheme. The rigid-lid approximation for the free surface was improved by replacing pressure, as a dependent variable, with water 
surface elevation. Water depth was then introduced in the continuity equation and had to be solved as another time-dependent variable. The governing equations are the depth-averaged versions of mass balance and momentum balance for shallow water, unsteady flows:

$$
\begin{aligned}
& \frac{\partial z_{w s}}{\partial t}+\frac{\partial(h U)}{\partial x}+\frac{\partial(h V)}{\partial y}=0 \\
& \frac{\partial U}{\partial t}+\mathrm{U} \frac{\partial U}{\partial x}+\mathrm{V} \frac{\partial U}{\partial y}=-\mathrm{g} \frac{\partial z_{w s}}{\partial x}+T_{x}-C h^{-1} \mathrm{U}|\mathbf{U}| \\
& \frac{\partial V}{\partial t}+\mathrm{U} \frac{\partial V}{\partial x}+\mathrm{V} \frac{\partial V}{\partial y}=-\mathrm{g} \frac{\partial z_{w s}}{\partial y}+T_{y}-C h^{-1} \mathrm{~V}|\mathbf{U}|
\end{aligned}
$$

Where $z_{w s}$ is the water surface elevation, $\mathrm{h}$ is the flow depth, $\mathrm{U}$ and $\mathrm{V}$ are the depth-averaged velocity components in the $\mathrm{x}$ and $\mathrm{y}$ directions, $|\mathbf{U}|$ is the modulus of the depth-averaged velocity vector, $\mathrm{T}$ is the force due to viscous effects, and $\mathrm{C}$, a friction coefficient. The local acceleration and convective components of acceleration are on the left hand side of equations 2 and 3 ; on the right hand side, there are the most important forces (per unit mass) considered in this model, i.e., gravitational force, the forces that arise in a turbulent flow due to momentum exchange, and the force due to the interaction of the flow and the channel bed. Secondary current and sidewall effects were discarded. However, the stream line curvature was considered later for estimating the near bed velocity that drives the movement of gravel on the bed (Nagata et al., 2000).

The friction coefficient is related to the bed roughness using Keulegan's (1938) equation and Kamphuis's (1974) experimental results:

$$
\begin{aligned}
& C^{-2}=2.5 \ln \left(11 \frac{h}{k_{s}}\right) \\
& k_{S}=2 D_{90}
\end{aligned}
$$

These formulae account for energy losses due to grain roughness. Kamphius conducted experiments on flumes with flat bed and his results were corroborated by Wong and Parker (2003). However, gravel-bed rivers have a non-uniform channel composed of riffles, pools with alternating bars and hence an extra dissipation term should be added for bed-form resistance. The use of just equations 4 and 5 in this study is supported by field measurements that indicate that at bankfull stages grain roughness accounts for all the resistance (Kaless, 2013). More details on the hydraulic model and the numeric methods can be found in Bernard (1993) and Kaless (2013). Further details on the Licanleufú model are also reported in Kaless (2013) and Kaless et al. (2013).

\subsection{Sediment transport model}

Sediment transport is modeled assuming local equilibrium conditions ( $\mathrm{Wu}, 2007)$, and using Exner's equation that relates spatial changes in sediment transport with temporal variation of bed elevation. It is expressed as:

$$
(1-\lambda) \frac{\partial z_{b}}{\partial t}=-\sum_{k} \nabla \cdot \mathbf{q}_{k}
$$


Where $\lambda$ is the bed material porosity, $z_{\mathrm{b}}$ is the bed elevation and $\mathbf{q}_{k}$ is the sediment transport vector for the $\mathrm{k}^{\text {th }}$ grain size class, which is evaluated with a sediment transport model. The sum on the right side indicates that the divergence must be evaluated for all grain size classes ( $k$ varies from 1 to $\mathrm{N}$, the number of grain classes).

The temporal evolution of the surface grain size distribution is described using the active layer approach (Hirano, 1971; Parker and Sutherland, 1990). For each grain size class there is a mass balance equation:

$$
\frac{\partial\left(L_{a} F_{k}\right)}{\partial t}=\frac{-\nabla \cdot \mathbf{q}_{k}}{\left(1-\lambda_{p}\right)}+f_{I k}\left(\frac{\partial L_{a}}{\partial t}-\frac{\partial z_{b}}{\partial t}\right)
$$

Where $L_{a}$ is the height of the active layer, $F_{k}$ and $f_{I k}$ are the surface and interface exchange grain fractions (for the $k^{\text {th }}$ grain size class), respectively. The active layer is assumed to have a height of the same order as the largest particles: $L_{a}=2 D_{90}$ (Parker et al., 2006). The interface grain size distribution $f_{I k}$ depends on whether the bed is degrading or aggrading. When the bed degrades $f_{I k}$ is equal to the substrate grain size distribution. On the contrary, when the bed aggrades a mixture between the bed load and the active layer material is adopted (Parker et al., 2006).

The bulk transport per unit width of the $k^{\text {th }}$ grain size class is calculated using Wilcock and Crowe's (2003) sediment transport model. Sediment transport is calculated considering the surface grain size distribution (GSD) and sand content. The latter is an important improvement of the WilcockCrowe model that affects the reference shear stress: the higher the sand fraction content, the lower the reference shear stress. The transport rate depends on the shear stress due to bottom roughness, which is evaluated using the Darcy-Weissbach equation:

$$
\tau=\rho C|\mathbf{U}|^{2}
$$

Where the friction factor $\mathrm{C}$ is evaluated using equation 4.

The direction of sediment transport depends on the direction of the main flow, the presence of secondary currents and bed topography. First, the direction of near bed flow relative to the main flow is calculated using the secondary flow correction. The influence of gravity is then included and depends on grain size, i.e., the trajectory of coarse grains will be more affected by gravity and fine grains will tend to follow bed flow direction. This process promotes spatial segregation (see Kaless, 2013, for more details).

\subsection{Bank erosion model}

Sediment transport near the banks is expected to produce local erosion. The heuristic model proposed by Jang and Shimizu (2005) has been adopted for modeling the bank failure. When the slope exceeds the angle of repose (assumed to be $\tan \phi=\mu_{d}$, the dynamic Coulomb coefficient) a failure surface inclined at the angle of repose is extended up to the floodplain surface. All the sediment above the failure lines moves downstream to form a deposit with a linear upper surface. The new surface grain size distributions for deposited and eroded areas are evaluated considering a mixture between the previous surface layer and the substrate material (see Kaless, 2013). Bank retreat occurs when bank failure moves the bank line outside the current domain. When this 
happens, a new mesh is created considering that cross sections are equally spaced along the centreline of the channel. Then points across the sections are also placed considering equal spacing. The surface grain size distribution is calculated by interpolation.

\subsection{Boundary conditions}

The boundary conditions consist of the specification of water and sediment fluxes and their distribution along the upstream cross section and water level at the downstream end, for which the normal flow is adopted. Flow through the lateral boundaries is not allowed. Because flow is unsteady, a specific treatment (drying/wetting processes) was considered for inner and lateral boundaries. The domain is divided into "dry" and "wet" cells if water depth is below or above a minimum value, respectively (see Kaless, 2013, for further details).

\subsection{Numerical methods}

A finite-volume discretization scheme with a curvilinear boundary-fitted grid was adopted. The location of dependent variables is specified according to a staggered grid: fluxes $\left(Q_{U}\right.$ and $\left.Q_{V}\right)$ are calculated at face-centre, and scalar variables (water surface elevation, turbulent kinetic energy $\mathrm{k}$, dissipation rate $\varepsilon$, sediment transport, bed elevation and grain size distributions) are calculated at cell-centre. The cell-centred depth-averaged velocities $U$ and $V$ are computed from $Q_{U}$ and $Q_{V}$ only when they are needed, for instance, to compute the viscous, friction forces and bottom shear stress.

Advection terms require specific numerical methods in order to avoid instabilities: a) the momentum equations are solved applying MacCormack's predictor-corrector scheme, adapted from Bernard (1993) for solving a free surface flow; b) the transport equations of the Standard k- $\varepsilon$ model are solved using the Euler (first order) upwind scheme; and $c$ ) the Exner equations (for bed elevation and grain size distribution) use Euler's scheme with the HLPA interpolation method for the divergence term (Zhu, 1991).

Flow and sediment transport calculations are decoupled because bed changes are very slow. First, the flow equations are solved considering a fixed bed, and then sediment transport is calculated considering water surface and discharge fixed (but water depth and mean velocity are adjusted considering bed elevation changes). For "short-term" simulations a tolerance is imposed for bed change and when this is exceeded, the hydraulic parameters are updated solving the flow equations. Instead, for a "long-term" simulation that normally spans several days, hydraulic parameters are held fixed during the time step of the hydrograph (normally assumed to be one day). Because the initial conditions differ with respect to the steady state flow an unsteady flow will occur. The hydrodynamic calculation stops when the difference between the discharge through all the cross sections and the incoming discharge is below a given tolerance.

\section{Validation of the model}

The hydraulic model has been extensively tested in previous studies. Bernard (1993) presented a comparison of laboratory measurements and model predictions for a double bendway trapezoidal channel. The model was also applied successfully to natural meandering rivers (Rodriguez et al., 2004). More recently, Abad et al. (2008) also applied STREMR to meandering rivers but they 
extended the model to perform sedimentological simulations (STREMR HySed). They showed that the correction due to secondary flow was capable of capturing the location of erosion and deposition areas. All these examples refer to meandering rivers where an important role of the secondary circulation is expected. With regards to gravel bed rivers, Lane and Richards (1998) used STREMR to study in detail the flow properties in a small braided stream in a proglacial area of Switzerland. They concluded that the secondary circulation correction had little effect upon velocity predictions and underlined the importance of roughness specification as a source of error for velocity prediction. They also found that the effect of sidewall correction was negligible.

Three tests are presented for assessing specific features introduced in the Licanleufú 2D model: sediment transport, bed armouring and morphological changes.

\subsection{Test 1: sediment transport in a narrow channel with mobile bed.}

The first test was conducted to assess the performance of the Wilcock-Crowe (2003) sediment transport model under conditions of mobile bed armour.

\section{Experiment set-up.}

The experiments were conducted in a $8 \mathrm{~m}$ long, $0.3 \mathrm{~m}$ wide laboratory channel, with a slope of $0.01 \mathrm{~m} \mathrm{~m}^{-1}$. Channel walls were made of Plexiglas. Sediment was collected at the downstream end of the flume using a full-width trap. At the beginning of each experiment, the sediments were thoroughly mixed and then screeded flat to a thickness of $0.13 \mathrm{~m}$. The mixture had a bimodal grain-size distribution ( $20 \%$ sand - $80 \%$ gravel) with $D_{16}=1.7 \mathrm{~mm} ; D_{50}=6.2 \mathrm{~mm} ; D_{84}=9.8 \mathrm{~mm}$. Sediment was recirculated manually allowing the formation of a mobile armour layer. Eight runs were performed with discharges ranging from 7.1 to $25.61 \mathrm{~s} \mathrm{~s}^{-1}$. Water depth was measured at 11 positions along the flume. Final surface grain size distribution was calculated from 8 photos (area: $0.20 \times 0.15 \mathrm{~m}$ ) using the grid-by-number approach (for more details on the experiment set-up see Mao et al., 2011).

$\underline{\text { Results. }}$

The Wilcock-Crowe model was applied using measured surface grain size distribution, water depth and slope. Shear stress was corrected for side-wall effects considering a bed roughness ks = 2. $D_{90}$ (Kamphuis, 1979; Wong and Parker, 2006). Total sediment transport was calculated for each run. Figure 1 shows the comparison between predicted and observed sediment transport. Sediment transport calculated with Wilcock and Crowe's model appears to be biased as the formula tends to overpredict at low flows $\left(\tau_{c}{ }^{*}=0.037\right)$ by a factor ranging from 4.5 to 18 times the observed values $(p$-value $<0.001)$. However, at higher flows $\left(\tau_{c}{ }^{*}>0.050\right)$ the predicted values are much closer to the observed ( $p$-value $=0.066$ ), thus the model seems to be more reliable for high shear stress intensities. Application of the Licanleufú model to the Brenta River will be used to predict morphological changes due to the occurrence of three flood events. The computed dimensionless shear stresses are within the range $0.20-0.40$ (i.e., much higher than the experimental range), and thus the bias for low shear stresses should not considerably affect the model performance. 


\subsection{Test 2: static amour development in a wide channel.}

The second test is intended to assess the capacities of the sedimentological model considering the sediment transport and the variation in surface grain size distribution simultaneously.

\section{Experiment set-up}

The experimental channel was $2 \mathrm{~m}$ wide and $11 \mathrm{~m}$ long with a longitudinal slope of $0.005 \mathrm{~m} \mathrm{~m}^{-1}$. Sidewalls were made of Plexiglas, so bank erosion was not possible. Eight traps covering the whole channel width were used to collect the transported sediments. Traps were removed and emptied at variable intervals in order to derive bedload transport rates and grain size. The bulk gravel-sand mixture had the following percentiles: $D_{16}=4.1 \mathrm{~mm}, D_{50}=6.4 \mathrm{~mm}$ and $D_{84}=13.1 \mathrm{~mm}$. At the beginning of the experiment sediments were screeded flat to the specified bed slope. Pressure transducers were placed beneath the sediments along the channel centre for measuring the water surface elevation. A run was performed with a water discharge of $340 \mathrm{I} \mathrm{s}^{-1} \mathrm{~m}^{-1}$. The experiment continued until the outgoing sediment transport was $1 \%$ the initial value. At this point photos were taken of the bed surface and the grid-by-number approach was used to evaluate the average surface grain size distribution.

\section{Model set-up}

The initial water surface elevation was calibrated against measurements so as to ensure similar hydrodynamic conditions in the flume and model. Bed roughness was also verified and a value of $\mathrm{ks} / \mathrm{D}_{90}=2$ was adopted. Because there was no armour at the initial state, the surface grain size distribution was assumed equal to the bulk sand-gravel mixture. Bed material (substrate and active layer) was divided in 13 grain size classes ranging from $0.7 \mathrm{~mm}$ to $64 \mathrm{~mm}$. In this way, 5 classes described the sand component and 8 the gravel component of the mixture. The mixture porosity was calculated using an empirical formula proposed by Wu and Wang (2006), giving the value $\lambda=0.27$. The following boundary conditions were assumed for the simulations: a) fixed downstream water surface elevation; b) constant upstream incoming water discharge; c) null sediment supply; and d) minimum bed elevation at the downstream end (no erosion can take place below this level). The model was run under the "short-term" configuration considering a maximum bed elevation change of $2 \%$. The flow domain was defined by an orthogonal mesh with a grid size of $0.125 \mathrm{~m}$ in the transversal direction and $0.25 \mathrm{~m}$ in the flow direction.

\section{$\underline{\text { Results and discussion }}$}

During the experiment, the bed experienced degradation in its upstream end and a progressive bed surface coarsening. Sediment transport rate reached the highest intensity at the beginning of the experiments $\left(53 \mathrm{gr} \mathrm{m}^{-1} \mathrm{~s}^{-1}\right.$ ) and decreased quickly to below $1 \%$ of the initial rate after $45 \mathrm{hr}$ (Figure 2).

The calibrated run approached the maximum initial sediment transport rate $\left(45 \mathrm{gr} \mathrm{m}^{-1} \mathrm{~s}^{-1}\right.$, see run W2 in Figure 2). It is worth noting that, as the downstream water depth increases the predicted initial transport rate decreases significantly (28 and $17 \mathrm{gr} \mathrm{m}^{-1} \mathrm{~s}^{-1}$, for runs W6 and W7, respectively). After the first hours of simulation, as sediment transport decreases, the model 
overpredicts the sediment transport, confirming that sediment transport is better predicted at higher intensities (above $10^{-5} \mathrm{~m}^{2} \mathrm{~s}^{-1}$ ) and overpredicted at lower intensities (below $10^{-6} \mathrm{~m}^{2} \mathrm{~s}^{-1}$ ).

With regard to the GSD of outgoing bed load, all the runs predicted the same distribution. The predicted GSD approximated well the observed GSD for the lower percentiles $\left(D_{16}, D_{50}\right.$, Table 1$)$, i.e., the predicted median diameter was very close to the observed mean value. There is instead a clear discrepancy for the coarser fractions, as the predicted percentile $84 \%$ is somewhat lower than the observed. However, if the final surface GSD is considered, the predicted values are similar to measurements and range within the uncertainty band (see also Table 1). In the case of $D_{84}$, while the predicted value was $16.1 \mathrm{~mm}$, measurements were in the range $15.2 \mathrm{~mm}-20.3$ $\mathrm{mm}$.

Previous researches have shown that armouring development occurs into two phases: a first phase when the bed degrades and then a second one when the surface coarsens due to selective transport of fine sediments at flows below the threshold for entrainment of larger grain sizes, so the bed surface is winnowed of the most easily moved fine sediment (Church et al., 1998; Wilcock et al., 2001; Mao et al., 2011). When the static armour layer has developed local exchange with the bed ceases.

The application of the model showed that during the first phase sediment transport decreases as bed slope reduces (i.e., it is entirely governed by hydraulics). The second phase was also present in the experiment: although the final surface grain size distribution was only slightly coarser than the initial one, an incipient static armour developed. The measured absolute degree of armouring was $D_{50} / D_{50 s s}=1.26$, while the predicted one was 1.17 . This indicates that selective transport took place in the flume. Fractional transport rates were also calculated using sediment transport rates at the beginning and end of the experiment. For the initial state, the initial bulk GSD was considered, while the final surface GSD was used for the final fractional rate. Resulting curves (Figure 3) show that at the beginning of the experiment, when there was no armour layer, all the grain fractions were transported (full transport) whereas by the end of the experiment partial transport occurred. Coarse material remained on the bed while fine grains were winnowed. On the contrary, Wilcock-Crowe's model predicts selective transport in all the sediment transport stages, because full transport conditions were not included in their experiments.

The presented results further reveal how challenging it can be for a transport equation to take into account the influence of shear stress on the fractional transport rate. In fact, although included in the structure of the equation, very high shear stresses would be required to achieve a condition of full transport. In the application to the Brenta River, the computed dimensionless shear stresses range between 0.20 and 0.40 , i.e., about 6 to 13 times the reference shear stress $\left(\tau_{c}{ }^{*}=0.03\right)$, which would certainly produce full transport conditions, leading to an underestimation of the transport of the coarser fractions.

\subsection{Test 3: morphological changes in a large erodible stream.}

The objective of the third test was to assess the performance of the morphological module, i.e., to test its capacity to predict both bed and bank changes. 


\section{Experiment set-up.}

Schmautz (2003) performed a series of experiments in a sand excavated stream within a wider channel. The "Isar" run was selected for the present study: the stream was $72 \mathrm{~m}$ long and had a trapezoidal cross section, $3.25 \mathrm{~m}$ wide at the bottom and $3.78 \mathrm{~m}$ at the top. The stream depth was $0.133 \mathrm{~m}$ and its slope was $0.0085 \mathrm{~m} \mathrm{~m}^{-1}$. The stream bed and bank material was composed of a mixture of $90 \%$ sand and $10 \%$ fine gravel (material was in the range $0.064 \mathrm{~mm}-5 \mathrm{~mm}$, with mean diameter $\mathrm{Dm}=1.2 \mathrm{~mm}$ ). Discharge was held constant during the experiment at $243.2 \mathrm{I} \mathrm{s}^{-1}$ and water surface elevation was set at the bankfull level at the downstream end. The experiment lasted for $53.7 \mathrm{~h}$ but channel width attained equilibrium at $26.8 \mathrm{~h}$.

\section{Model set-up.}

The water surface bankfull level condition in the experiment was used to calibrate the roughness parameter, and a value of $k s / D_{90}=1$ was selected. Schmautz (2003) reports sediment transport measurements used to calibrate Peter-Meyer and Müller's model. The calibrated relation was used in this study to verify the performance of Wilcock-Crowe's model for the range of shear stress found in the stream. Two runs were prepared: the first represented bed material with 11 grain size classes and the second had only one grain size class (with the same mean geometric diameter and $\mathrm{D}_{90}$ ). In this way, armour development was allowed in the first run but was inhibited in the second. The porosity of the mixture was calculated using the empirical formula proposed by Wu and Wang (2006), giving the value $\lambda=0.34$. The following boundary conditions were assumed for the simulations: a) fixed downstream water surface elevation; b) constant upstream incoming water discharge; c) null sediment supply; and d) minimum bed elevation at the downstream end (no erosion can take place below this level). The model was run under the "short-term" configuration considering a bed elevation change tolerance of $2 \%$. An orthogonal mesh was used with a grid size of $0.50 \mathrm{~m}$ in the flow direction and a variable size in the transversal direction; the grid was coarser in the channel center $(0.38 \mathrm{~m})$ and finer in the bank region $(0.03 \mathrm{~m})$ because shear stress changes strongly near the banks.

Results and discussion.

Bed degradation was observed in the experimental stream, starting at the upstream end and propagating downstream as the experiment proceeded. At time $26.8 \mathrm{~h}$ bed degradation extended over $26 \mathrm{~m}$. Downstream of this point, the bed was almost in equilibrium and had nearly the same elevation as the initial state (actually it was $2 \mathrm{~mm}$ above the initial bed). Figure 4 shows the bed profile at the end of the simulation (time $26.8 \mathrm{~h}$ ). The elevation is defined as the mean bed level along the initial bottom width. Run 1 predicted also bed erosion at the upstream end, however it affected a smaller sub-reach (comprising from $x=0 \mathrm{~m}$ to $\mathrm{x}=8.5 \mathrm{~m}$ ). Downstream of this subreach, the model predicted the same mean bed elevation as the observations. The effect of the armour layer development is quite evident in this simulation. Figure 4 also includes the armour ratio (surface median diameter / subsurface median diameter), which has a value of 2 at the upstream end and lowers downstream but remains above 1 . When the armour layer development option was inhibited in Run 2, a deeper erosion was predicted upstream which is very similar to observations. A discrepancy remains between cross sections located at $x=8 \mathrm{~m}$ and $\mathrm{x}=25 \mathrm{~m}$, which has not been explained. 
The stream width was measured at half the depth of the stream (mean bed elevation was calculated considering the initial bottom width). At the beginning of the experiment the stream width was $3.5 \mathrm{~m}$. Bank erosion then occurred, widening the stream until the equilibrium state was reached at time $26.8 \mathrm{~h}$. Figure 5 shows the downstream variation of the width at this moment. In the first $29 \mathrm{~m}$ the width changed from $3.4 \mathrm{~m}$ to $3.95 \mathrm{~m}$ and then remained nearly constant with a mean value of $3.96 \mathrm{~m}$. The cross section predicted by Run 1 was narrower than measurements (mean width $3.67 \mathrm{~m}$ ). Again, it was due to the stabilizing effect of bed armouring that reduced the lateral sediment transport and bank retreat. The calculated armour ratio was 1.5 at the bank toe. Instead, Run 2 predicted a cross section very similar to the observed one in the sub-reach between cross sections located at $x=29 \mathrm{~m}$ and $\mathrm{x}=70 \mathrm{~m}$ (mean value $3.99 \mathrm{~m}$ ). Upstream of this sub-reach, predictions differed from observations: the width changed faster and reached the stable value before observations. This discrepancy may be related to boundary perturbations in the experiment that are not present in the simulations. Figure 4 shows an anomalous bed curvature inversion between cross sections located at $x=9 \mathrm{~m}$ and $\mathrm{x}=25 \mathrm{~m}$ that was not predicted by the model.

Although run 1 was set up considering the whole range of sediment sizes, questions arise on the applicability to a sand-bed stream of a sediment transport model developed for gravel-bed rivers. For instance, the development of the armour layer predicted by the model is not to be expected in a sand-bed river. While the development of the armour layer in the model produced bias in the results, when the transport model was tested against measurements and the bulk transport was considered inhibiting the possibility of armour layer development, the predicted values agreed with measurements, validating the bank erosion model.

\section{Field Application}

A field application of the model is presented considering a reach of a gravel bed river, the Brenta River (Italy). The application is focused on a) assessing bed material transport, sediment budget and dynamics, b) interpreting channel response to a series of intensive flood events (R.I. > 9 years) that occurred in 2010, and c) providing a possible evolutionary scenario of the Brenta River in the medium term.

\subsection{Physiographic features}

The Brenta River originates in the Italian pre-Alps (Figure 6). In its upper part the river flows through a typical glacial-fluvial valley (U-shaped), the Valsugana Valley, from the Caldonazzo Lake. The river then flows across the wide Venetian Plain and drains into the Adriatic Sea. The lower part of the basin can be divided into an old deposition plain (alluvial fan of Bassano, Upper Pleistocene) on the left side of the river, and a more modern plain, the current Brenta River floodplain (Holocene). The study reach is in the lower part. The Brenta River basin has an area of $2280 \mathrm{~km}^{2}$, of which $1160 \mathrm{~km}^{2}$ are in the mountain region. The basin has a humid temperatecontinental climate. Mean annual precipitation is $1313 \mathrm{~mm}$, with maximums in spring (May-June) and autumn (October-November). The flow regime is characterized by low discharges during most of the year. The bankfull discharge is equal to $298 \mathrm{~m}^{3} \mathrm{~s}^{-1}$ and has a statistical duration of 3.5 days and a return interval of 1.3 years. 
The study reach of the Brenta River is $4.7 \mathrm{~km}$ downstream of the Barziza gauging station, near Bassano del Grappa (Veneto Region, see Figure 6). The reach is $1400 \mathrm{~m}$ long and the active channel is, on average, $73 \mathrm{~m}$ wide with a slope of $0.0039 \mathrm{~m} \mathrm{~m}^{-1}$. The bankfull mean depth is $1.4 \mathrm{~m}$ with a maximum depth of $2.8 \mathrm{~m}$ in the pools. The bed material is composed of a gravel-sand mixture with $D_{50}=24 \mathrm{~mm}$ and a sand content of $15 \%$. The bed surface is rather armoured and the $D_{50}$ is approximately $48 \mathrm{~mm}$. The Brenta River exhibits a single-thread channel which is mainly incised and has a floodplain confined by levees. Along the left bank, artificial rip-raps inhibit channel widening, whereas the right bank is free to erode.

\subsection{Data acquisition and digital terrain model development}

A detailed representation of the elevations in the study reach (DTMs), which includes the wet areas, has been generated using the approach previously presented by Moretto et al. (2014a). The necessary data for DTMs generation was obtained by two LiDAR surveys. The first LiDAR survey dates to 2010, and the second was conducted in 2011, after two significant floods in November and December 2010. For each LiDAR survey, a point density able to generate digital terrain models with $0.5 \mathrm{~m}$ of horizontal resolution (at least 2 ground points per square meter) was required. LiDAR data were taken along with a series of aerial photos with $0.15 \mathrm{~m}$ pixel resolution.

In order to integrate the elevation of wet areas in the DTMs generated with the LiDAR data, inchannel dGPS (Differential Global Positioning System) points were also acquired, taking different depth levels in a wide range of morphological units. Overall, 882 (in 2010) and 1526 (in 2011) points were surveyed.

The edges of the wet areas and reliable LiDAR points able to represent the water surface elevation (Zwl) were selected. The intensity of the colour bands and Zwl were added to the points acquired in the wet areas obtaining a shape file of points containing five fields (in addition to the spatial coordinates $X$ and $Y$ ): the intensity of the three colour bands, Red (R), Green (G), Blue (B), the elevation of the channel bed (Zwet) and Zwl. Finally, the channel depth was calculated as Dph $=Z w l-Z w e t$. An empirical linear model for each year (2010 and 2011) between depth and the associated colour bands intensity was tested and applied.

The best bathymetric model was applied to the georeferenced photos to determine the "Raw channel Depth raster" (RDph). The RDph was then filtered in order to delete incorrect points, mainly due to sunlight reflections, turbulence, and elements (wood or sediment) above the water surface. The corresponding Zwl was added to the corrected points (Dph model) to obtain, for each point, the estimated elevation of the river bed $(Z w e t=D p h+Z w l)$. Hybrid DTMs $($ HDTM) were built up with the natural neighbour interpolator, integrating Zdry points (by LiDAR) in the dry areas and Zwet points (by colour bathymetry) in the wet areas. The final step was the validation of the HDTM models which was performed by comparison with an independent dataset of dGPS control points in both dry and in wet areas (for further details see Moretto et al., 2014a).

In order to assess morphological changes due to the flood events, a DEM of Difference (hereinafter DoD) was generated from the HDTMs in $\mathrm{ArcGIS}^{\circledast}$. The propagation of the elevation uncertainty associated with the DoD was calculated by using the Geomorphic Change Detection 5.0 (GCD) software developed by Wheaton et al., 2010 (http://gcd.joewheaton.org). Slope, point density and bathymetric points quality were considered as potential sources of uncertainty of the 
final DoD. An "ad hoc" FIS file (Fuzzy Logic application) was created using Matlab ${ }^{\circledR}$ in order to consider the uncertainty variables in the GCD software. Local environment and the related literature (Wheaton et al., 2010, Moretto et al., 2014a) were used to define the categorical limits (low, medium, high) of slope, point density and bathymetric points quality. Geomorphic changes and their associated uncertainty along the study reach were finally calculated.

\subsection{Grain size surveys}

Samples of surface material were taken at 5 cross sections (covering a sequence riffle-pool-rifflepool-riffle) in order to describe the spatial variability of grain size. A grid-by-number scheme was adopted to sample pebbles over dry portions of the channel. The grid was also extended into wet areas where possible. Following Rice and Church (1996), at least 120 particles were measured on each sampling site, for an overall number of about 700 pebbles along the reach. Two samples of subsurface sediments were also taken from lateral bars. In taking these samples, a surface layer of approximately the local maximum surface grain was removed. The substrate material was then extracted and sieved in the laboratory. The total dried weight of the two samples was $336 \mathrm{~kg}$.

\subsection{Boundary conditions and numerical set-up}

Four scenarios of different upstream sediment supply were considered in the study. The first (named Run 1) represents a condition of mass equilibrium, i.e., the reach receives a sediment supply equal to the volume of material exiting the reach. In subsequent runs the total sediment supply volume was reduced so as to simulate conditions of sediment deficit as observed in the field (the difference of DTMs indicates a loss of $57810 \mathrm{~m}^{3}$ of material during the study period). The temporal distribution of sediment supply was calculated in Run 1 but proportionally adjusted with the total volume adopted for each other. Sediment supply was introduced the actual upstream cross section; the upstream sub-reach was considered an approach reach in order to buffer possible boundary inaccuracies.

The GSD of the sediment supply was equal to the substrate material and was kept constant over the simulations. This condition is a simplification that is unlikely to hold in the field because the GSD of the transported material will depend on previous flood magnitude, history of recent events, and duration of recent effective and even below-threshold flows (Hassan et al. 2006; Paphitis and Collins, 2005; Monteith and Pender, 2005; Mao, 2012, Recking et al., 2012). However, this assumption needs to be made when no data are available. Model results indicate that the transported GSD depends on flood magnitude, for instance the median grain size changed in the range between 9.6 and $19.4 \mathrm{~mm}$. When the total bulk of material transported during the simulation is considered, the surface GSD approaches the substrate GSD, the median diameter being equal to $16.6 \mathrm{~mm}$.

The data available for the period August 23, 2010 - April 24, 2011 (coinciding with the dates of the LiDAR flights) consisted of mean daily discharges as measured at the Barziza gauging station. Since low discharges do not produce morphological changes, a minimum threshold of $150 \mathrm{~m}^{3} \mathrm{~s}^{-1}$ was selected and only higher discharges were used in the numerical simulations. A number of preliminary numerical runs verified that this discharge could entrain at least $41 \%$ of the size range (considering a reference dimensionless shear stress of 0.045). Discharges below $150 \mathrm{~m}^{3} \mathrm{~s}^{-1}$ were removed from the original record but the sequence of discharges was conserved. The resulting 
record to be modeled had a length of 35 days, out of the total of 244 in the study period. The record includes three important flood events with peak daily mean discharges of $720 \mathrm{~m}^{3} \mathrm{~s}^{-1}$ (R.I. = 8 years), $545 \mathrm{~m}^{3} \mathrm{~s}^{-1}$ (R.I. = 3.3 years) and $759 \mathrm{~m}^{3} \mathrm{~s}^{-1}$ (R.I. = 9.5 years)

The DTMs obtained by LiDAR surveys had a cell dimension of $0.5 \mathrm{~m} \times 0.5 \mathrm{~m}$. However, the simulation was performed with a mesh composed of coarser cells. It was therefore necessary to take the spatial average of elevations within each cell in the simulation domain. This procedure was applied to the initial and final DTMs so as to provide the initial channel configuration for the simulation, but also a common frame for subsequent comparisons. The domain was divided into 111 cells in the downstream direction and 60 cells cross-wise. On average, cells were $12.6 \mathrm{~m}$ in length and between 2.00 to $4.00 \mathrm{~m}$ in width.

The reach averaged surface grain size distribution was assigned to each cell at the beginning of the simulation. The surface material had the following percentiles: $D_{16}=16.0 \mathrm{~mm}, D_{50}=48.2 \mathrm{~mm}$ and $D_{84}=136.5 \mathrm{~mm}$; and the bulk gravel-sand mixture was finer and had the percentiles $D_{16}=3.7$ $\mathrm{mm}, \mathrm{D}_{50}=24.1 \mathrm{~mm}, \mathrm{D}_{84}=79.9 \mathrm{~mm}$. The material was represented in the model with 18 grain classes ranging from 0.5 to $512 \mathrm{~mm} ; 3$ classes were used for sand and 15 for gravel. To consider ripraps and unmovable structures, a much coarser and immovable grain size was assigned, and a higher friction angle was set in the model (e.g. $89^{\circ}$ ); otherwise, an angle of $37^{\circ}$ was adopted for the mixture of gravel and sand. Sediment porosity was calculated using Wu and Wang's (2006) formula, and it was equal to 0.241 . Because a uniform GSD was used, bed surface is expected to change during the first time steps adjusting to the empirical sediment transport model. Although a previous warm-up phase was not included, the first day of the simulation (with a low discharge of $158 \mathrm{~m}^{3} \mathrm{~s}^{-1}$ ) functioned in this way and it was verified that minor changes took place: bed elevation changed $1.6 \%$ (taking the entire simulation as a reference), and the surface $D_{50}$ changed in the range $-17.3 \%+26.9 \%$ of the original value. A longer warm-up period should be considered in future development of the application to improve the model performance.

At the downstream end of the study reach, a minimum bed elevation was imposed (i.e. no erosion allowed) and the water surface elevation was fixed at the uniform-flow depth. It was later verified that this minimum elevation did not impose a limit on bed incision.

\subsection{Model validation}

A series of test runs was performed first to validate the hydraulic model. Water surface elevations were recorded during a bankfull flood $\left(Q=298 \mathrm{~m}^{3} \mathrm{~s}^{-1}\right)$ that had occurred before the LiDAR survey in 2010, and during the peak discharge $\left(Q=759 \mathrm{~m}^{3} \mathrm{~s}^{-1}\right)$ for the event in December 2010. Because channel morphology changed between 2010 and 2011, it was not reliable to test the model against the highest discharge. The bankfull discharge event provided a good test because the entire channel was wetted and negligible changes occurred (according to a comparison between cross sections surveyed before the event and the LiDAR survey). Figure 7 shows the comparison between bankfull levels and predicted water surface elevation for the calibrated roughness parameters. The best agreement was obtained for $\mathrm{ks} / \mathrm{D}_{90}=2$, and hence this value was adopted for the subsequent runs (mean absolute error $=0.27 \mathrm{~m}$, and root mean square $=0.40 \mathrm{~m}$ ). The ratio $\mathrm{ks} / \mathrm{D}_{90}$ is kept constant in the model but ks can change as $D_{90}$ changes in each cell as the simulation progresses. 
Downstream water surface elevation was also changed so as to assess its effect on the water profile. The energy gradient slope was changed by $\pm 20 \%$ around the mean reach value $(0.0039 \mathrm{~m}$ $\mathrm{m}^{-1}$ ) and the water surface elevation changed $\pm 0.12 \mathrm{~m}$. The backwater extended only for $110 \mathrm{~m}$, and beyond this point water surface elevation was not changed. This is acceptable given the channel slope and bed roughness $\left(D_{90}=181 \mathrm{~mm}\right)$.

\subsection{Results}

A first qualitative comparison between model results and field observations is made by considering the difference in bed elevation (DoD) at the beginning and end of a simulation. Figure 8 shows four numerical simulations of morphodynamic changes under the four imposed sediment supply scenarios, and the field observations. As expected, the higher the sediment supply is, the larger the spatial extent of deposition areas (in green) along the reach. Likewise, as sediment supply is reduced sectors with deposition become relatively less frequent and are replaced by erosion areas (in red).

The study reach can be divided in three sub-reaches if the siltation/erosion trends are considered: the approach, middle and the final sub-reach (see Figure 6). The approach sub-reach is located in the upstream part of the reach and is more evident in Runs 2 to 4 , as a sector dominated by bed incision. This process is not evident in the field, where instead there was bank erosion. The approach sub-reach works as a transition, a buffer sub-reach, where the input sediment transport, imposed in the boundary, evolves to the actual sediment transport capacity of the reach. The extension of this sub-reach is approximately $450 \mathrm{~m}$ (or 6 times the channel width). The second sub-reach can be identified from $450 \mathrm{~m}$ to $1200 \mathrm{~m}$. It is characterized by a series of alternating siltation and erosion sectors, the location of which is correctly predicted by the model. Moreover, bank erosion along the right bank is predicted in the same sector where it was observed. The sub-reach end is defined by the location of a siltation sector that is not present in the field. This sector is more possibly affected by backwater due to inaccuracies in the determination of the downstream water surface elevation.

Mass balance was calculated across the channel in order to provide a quantitative comparison of siltation and erosion sectors along the reach. The bulk was converted into sediment volume correcting with the material porosity using the following approach:

$$
V_{s}=(1-\lambda) \cdot V
$$

Where $V_{S}$ is the volume of sediments, $V$ is the bed material bulk that includes voids, and $\lambda$ is the material porosity. Figure 9 shows the downstream trend of erosion/deposition, with positive differences indicating siltation and negative values erosion. Uncertainty bands were also calculated for observed volume differences (a range of 1 times the uncertainty around the mean value corresponds to a $68.3 \%$ probability, and the range around two times the uncertainty corresponds to a $95.4 \%$ probability). A marked difference is observed between field measurements and the outcomes of Run 1 that represent a state of mass equilibrium. Predictions lie above the observations far from the range of uncertainty (probability lower than $2.5 \%$ ). The last Run, corresponding to the scenario with lowest sediment supply (only $25 \%$ of sediment recirculation), plots closer to field observations. The three sub-reaches can be examined in terms 
of mass-balance. Predictions are within the range of uncertainty (for $95 \%$ probability) in the subreach between cross sections located at $x=300 \mathrm{~m}$ and $\mathrm{x}=1250 \mathrm{~m}$, i.e., the middle sub-reach. However, there is a general trend of downstream siltation that is higher for predictions than observations (two linear models were fitted and the slopes resulted as significantly different $-p$ value $<0.01$ ). In the approach sub-reach (cross sections between $x=0 \mathrm{~m}$ and $x=300 \mathrm{~m}$ ) predictions are lower than observations and there are overestimations in the final sub-reach (cross sections between $x=1250 \mathrm{~m}$ and $\mathrm{x}=1400 \mathrm{~m}$ ).

Although Run 4 is the only one that approximates the actual field observations, in all the simulations there seems to be a similar pattern of downstream bed variation. For instance, near the cross section at $x=400 \mathrm{~m}$ (Figure 9) there is a peak in the mass balance indicating siltation (Run 1) or low erosion (Run 4). What seems to emerge is a rhythmic pattern of alternating sectors with higher and lower erosion sectors. Figure 10 shows the downstream difference of massbalance between consecutive cross sections (which represents a rough approximation of the downstream spatial derivation). It is worth noting that after the cross section at $x=260 \mathrm{~m}$, all the curves collapse into one single band. This means that, in spite of different sediment supplies, all the runs predicted the same location for the transition between erosion/siltation sectors (maximum positive values), the transition from siltation to erosion sectors (minimum negative values), and erosion or siltation sectors (near zero values).

If the buffer sub-reach is excluded, the middle sub-reach can be considered for estimating the sediment budget of Brenta River. The mass deficit observed in the field was $39.577 \mathrm{~m}^{3}$ (with an uncertainty of $\pm 11.407 \mathrm{~m}^{3}$ ), which is $20 \%$ higher than prediction from Run 4 results. A linear extrapolation was adopted for evaluating the sediment supply in the study reach that was equal to $68.940 \mathrm{~m}^{3}$ (table 2). The output sediment bulk results from the sediment continuity equation. It is estimated that a sediment volume of $108,517 \mathrm{~m}^{3}$ was transferred to the downstream reach during the events taking place in the study period. A mean bed incision of $0.48 \mathrm{~m}( \pm 0.14 \mathrm{~m})$ was calculated dividing the mass deficit by the channel area and correcting for material porosity.

Because Run 4 predictions are nearest to the actual morphological evolution of the reach (the difference in mass balance is not significant, with $p$-value $=0.531$ ), sediment transport from this simulation was used to calibrate a relationship between water discharge and the output sediment transport. Two equations were fitted, one is a simple power-type formula and the second includes a threshold discharge (see Figure 11):

$$
\begin{array}{ll}
Q_{S}=1.48 \cdot 10^{-8} Q^{2.50} & \left(r^{2}=0.959\right) \\
Q_{S}=2.26 \cdot 10^{-7}(Q-50)^{2.09} & \left(r^{2}=0.953\right)
\end{array}
$$

Where Qs is the output sediment transport (in $\mathrm{m}^{3} \mathrm{~s}^{-1}$ ) and $\mathrm{Q}$ is the water discharge (in $\mathrm{m}^{3} \mathrm{~s}^{-1}$ ).

In order to assess the actual annual gravel supply in the Brenta river, data of mean daily discharge in the period $1954-2009$ were adopted. This period is after the construction of major dams in the upper basin (Surian and Cisotto, 2009). For each hydrological year a volume of sediments was calculated applying equations 10 and 11 , and the average gravel volume transported by the study reach (in the period 1954-2009) is $47.0 \times 10^{3} \mathrm{~m}^{3} \mathrm{yr}^{-1}$ and $36.4 \times 10^{3} \mathrm{~m}^{3} \mathrm{yr}^{-1}$, respectively. However, due to annual changes in discharge magnitude and duration, the volume varies widely. The 
standard deviation is as high as the mean value calculated: $43.8 \times 10^{3} \mathrm{~m}^{3} \mathrm{yr}^{-1}$ using eq. 10 and $37.4 \times 10^{3} \mathrm{~m}^{3} \mathrm{yr}^{-1}$ using eq. 11 . The annual supply varies in the range $2 \times 10^{3} \mathrm{~m}^{3} \mathrm{yr}^{-1}-2 \times 10^{5} \mathrm{~m}^{3} \mathrm{yr}^{-1}$.

Although sediment transport is not actually measured in the study reach, an indirect comparison of results can be made considering researches conducted on other gravel bed rivers. For instance, Barry et al. $(2004 ; 2007)$ provided means for the estimation of a sediment rating curve based on basin area, the 2-years flood and bed material. The derived formula for the Brenta River is:

$$
Q_{S}=6.5 \cdot 10^{-9} Q^{2.45}
$$

The coefficient provided by Barry et al. (2007) is 2.3 times smaller than the coefficient calibrated by the model, while the exponent is almost identical.

Bathurst (2007) developed another bed-load transport formula based on field and flume data. His formula introduces a linear dependence of bed-load with the excess discharge, i.e., above a threshold for sediment movement. In the case of the Brenta River, the threshold discharge as calculated following Bathurst's approach ranges between 1.39 and $1.71 \mathrm{~m}^{3} \mathrm{~s}^{-1} \mathrm{~m}^{-1}$ (i.e. 101 to 125 $\mathrm{m}^{3} \mathrm{~s}^{-1}$, if a mean channel width of $73 \mathrm{~m}$ is considered). The formula proposed by Bathurst (2007) applied to the Brenta River reads as follows:

$$
Q_{s}=5.7 \cdot 10^{-4}\left(Q-Q_{c r}\right)
$$

Where $Q_{c r}$ is the threshold discharge. The exponent in this formula differs significantly from previous results and the coefficient is much higher. Figure 11 provides a comparison of results. The results from the simulations are the consequence of application of the Wilcock-Crowe (2003) model combined with the hydraulic model and surface material data. These results stand below the predictions made by the Bathurst (2007) model and above those obtained by applying the Barry et al. $(2004 ; 2007)$ models.

\subsection{Discussion}

4.7.1 Calibration of the sediment supply with field high resolution data.

Sediment transport is extremely difficult to measure in the field, especially in large and dynamic gravel-bed rivers, and particularly during high magnitude flood events that exert the highest morphodynamic forcing to the system. Alternative approaches have been developed based on the river morphological changes (Lane et al., 1995; McLean and Church, 1999) or considering particle path lengths (Neill, 1987). The first approach has usually been applied in long reaches because it requires the application of the sediment continuity equation within sub-reaches (McLean and Church, 1999). The sediment output of one reach therefore constitutes the sediment supply for the downstream sub-reach. The method requires only the estimation of sediment supply at the first sub-reach and the input from tributaries within the reach. Surian and Cisotto (2007) applied this methodology to a $23 \mathrm{~km}$ long reach of the Brenta River (the study reach in this paper is at the upstream end of their study reach). They analyzed the morphological changes in 12 cross sections and estimated a sediment transport rate of nearly $25 \times 10^{3} \mathrm{~m}^{3} \mathrm{y}^{-1}$ at cross section 2 , in the period 1984-1997. The approach followed in this study used a 2D model to assess the possible sediment supply to a small reach (1400 $\mathrm{m}$ long). The model was calibrated comparing the river morphological changes as predicted by the model and measured with high resolution techniques 
in the field. The derived sediment rating curves were applied to calculate the annual sediment transport rate to the period 1987-1997 because there are gaps in the discharge record in the years 1984, 1985 and 1986 . The mean gravel supply is $34.0 \times 10^{3} \mathrm{~m}^{3} \mathrm{y}^{-1}$ using eq. 10 and $25.8 \times 10^{3}$ $\mathrm{m}^{3} \mathrm{y}^{-1}$ using eq. 11. The latter value is almost identical to Surian and Cisotto's findings. The result from eq. 10 is higher because the predicted sediment transport is higher for low discharges that have long durations in the Brenta River. At this range of low discharges, equation 11 may more adequately predict the sediment transport due to the inhibiting effect of the coarse surface layer (Bathurst, 2007).

Field surveys of sediment mobility and displacement length have recently been done in the Brenta River (Mao et al., submitted), and have been used to assess sediment transport by applying the so-called virtual velocity approach (see Wilcock, 1997). Although still preliminary, the first results take advantage of field assessed virtual velocity of sediment of different sizes, and thickness of the sediment active layer assessed using scour chains, and overall are suggesting that the bedload transport rate in the study reach may be in the order of $30 \times 10^{3} \mathrm{~m}^{3} \mathrm{y}^{-1}$.

As a final comment, although the Wilcock-Crowe (2003) formula was used in the sediment transport model without previous calibration with field data (as suggested by Wilcock, 2001), the comparison made of bulk annual transport derived from other methods supports the choice.

\subsubsection{Possible evolutionary scenario of the Brenta River in the study reach.}

Because the Brenta River study reach is located at the entrance of the river to the Venetian plain, it is severely conditioned by sediment supply. Sediment sources from upstream are limited by dams and so attention should be paid to within reach sources. A relevant question thus arises on whether the study reach will continue in its mild trend of bed incision (as revealed by Moretto et al., 2014b) if no management or restoration strategies are implemented. Erosion along the active channel may be affected by several factors: channel widening, the development of a static armour, or by fixing the boundary conditions at the bridge located near the downstream end of the reach.

The channel widening strategy has already been tested and applied in the field within the context of European gravel bed rivers. In an extensive flume research program carried out at the Technische Universität München - Germany (Schmautz and Aufleger, 2002; Aufleger and Niedermayr, 2004; Schmautz, 2004) bank processes were studied and the effect of "soft bank", i.e., banks that could be eroded, was tested as a valid source of sediments. Laboratory results alongside numerical simulations showed that the material removed from the banks could stop bed incision. Similar field evidence has also been reported by Habersack and Piégay (2006). In a restoration program on the Drau River (Austria) one goal was to stabilize the channel bed by increasing its width. In the case of the Brenta River, a significant proportion of the material deficit was made up by erosion along the banks of the channel (a quantification of the sediment volumes revealed that bank erosion supplied nearly $22.000 \mathrm{~m}^{3}$ of material during the floods, which is $38 \%$ of the total mass deficit). A possible river restoration scenario could entail the elimination of protection works existing along the right bank at the downstream part of the reach, where it would be possible to relocate three houses and build a new levee $100 \mathrm{~m}$ to $150 \mathrm{~m}$ from the current bank position. 
Recent researches carried out by Rigon et al. (2012) and Moretto et al. (2014b) pointed out the relation between flood magnitude and channel widening, and stressed the role of riparian vegetation. Overall, a higher magnitude of flooding corresponds to a higher active channel widening, and a reduction of the active channel width is due to the expansion of riparian vegetation establishing on floodplains and islands during periods without major disturbance processes.

The development of a static armour is also crucial for channel stability. Laboratory experiments reveal that there are two phases during the development of the armour: a first phase of incision and a second of coarsening (Church et al., 1998; Wilcock et al., 2001; Mao et al., 2011). Furthermore, static amour layers are highly structured and imbricated with higher thresholds for entrainment. The Brenta River is highly armoured, with a reach-average absolute armouring index of 2.32 (3.58 at riffles and 1.72 at pools). This level of armouring seems to be insufficient to prevent erosion when floods of high magnitude occur (R.I. up to 9.5 years) as indicated by the field observations which show that the whole reach was subject to erosion processes. However, the armour stabilization role may be stronger for ordinary floods ( $\mathrm{RI} \approx 2$ years).

\section{Conclusions}

The aim of this study was to assess the bed material transport and planform response and dynamics of the Nove reach of the Brenta River. The approach adopted high-resolution DTMS in combination with a 2D-depth averaged model. As a result, the annual bed material transported downstream was estimated at 36 to $47 \times 10 \mathrm{~m}^{3} \mathrm{y}^{-1}$, a value that is in the same order of magnitude as results coming from research applying the virtual velocity approach.

The reach was divided into three sub-reaches: approach, middle and final. The approach subreach had a length of six river widths, and worked as a buffer. The dynamics of sediment transport in the middle sub-reach has been described with acceptable biases by the model: predicted siltation areas, in-channel and bank erosion sectors. The final sub-reach is disturbed by boundary conditions.

The response of the channel planform in the medium-term has to distinguish ordinary events (above bankfull discharge, with $\mathrm{Q}=298 \mathrm{~m}^{3} \mathrm{~s}^{-1}$ and R.I. $\approx 1.5$ years) and high floods with recurrence interval above 8 to 10 years. With regards to ordinary events, due to the presence of a well armoured bed and low transport rates, no significant or only negligible changes are expected to be observed in the channel bed (considering also errors in determination of volume changes that render small changes difficult to discern). On the other hand, high floods are expected to produce widespread bank erosion and a mild trend of bed incision. Bank erosion accounts for almost $38 \%$ of material lost during floods, so the elimination of some protection works could be a possible river restoration scenario for preventing further bed incision.

The model was first tested against three laboratory experiments. The first experiment revealed that the sediment transport equation (Wilcock and Crowe model) overestimated sediment transport at low flows, but better agreement was found for higher flows. Results from the second test were consistent with previous results and call attention to the difficulty in predicting fractional and full transport conditions. Finally, the aim of the third test was to validate the 
morphological module. The model predicted well the bed profile and width of a laboratory stream when the development of the armour layer was inhibited in the model.

The model is representative of the current state of the art and model components are similar to those employed in several similar models. When there are many logistical problems associated with direct measurement of bed load transport, its accurate application seems to be useful in the assessment of the actual and near future response of gravel bed river planform configuration to flow variations and bed reworking.

\section{Acknowledgements}

This research has been conducted within the framework of the UNIPD Project "CARIPARO-Linking geomorphological processes and vegetation dynamics in gravel bed rivers" and the UNIPD Strategic Project GEORISKS, Research Unit TeSAF Department. Part of the research was also funded by both the SedAlp Project: Sediment Management in Alpine Basins: integrating sediment continuum, risk mitigation and hydropower, 83-4-3-AT, in the framework of the European Territorial Cooperation Program Alpine Space 2007-2013, and the PRIN20104ALME4ITSedErosion: "National network for monitoring, modeling and sustainable management of erosion processes in agricultural land and hilly-mountainous area". The laboratory experiments were supported by a Marie Curie Intra European Fellowship (219294, FLOODSETS) within the 7th European Community Framework Program while Luca Mao was based at the Department of Geography of the University of Hull (UK). The authors are also very grateful to Robert Bernard for providing useful suggestions while developing the hydrodynamic model. Michel Church and an anonymous reviewer are kindly thanked for their contributions that helped to improve an earlier version of this paper. Ms. Alison Garside is also thanked for her assistance in improving the language of the paper.

\section{References}

Abad JD, Buscaglia G, Garcia MH. 2008. 2D stream hydrodynamic, sediment transport and bed morphology model for engineering applications. Hydrological Processes 22: 1443-1459. DOI: 10.1002/hyp.6697.

Allan JC, Hart R, Tranquili V. 2006. The use of passive integrated transport (PIT) tags to trace cobble transport in a mixed sand-and-gravel beach on the high energy Oregon coast, USA. Marine Geology 232: 63-86. DOI: 10.1016/j.margeo.2006.07.005.

Aufleger M, Niedermayr A. 2004. Large scale tests for gravel-bed river widening. Proceedings, River Flow 2004 - International Conference on Fluvial Hydraulics, Naples, Italy. 163-171.

Barry JJ, Buffington JM, King JG. 2004. A general power equation for predicting bed load transport rates in gravel bed rivers. Water Resources Research 40, Doi:10.1029/2004WR003190.

Barry JJ, Buffington JM, King JG. 2007. Correction to "A general power equation for predicting bed load transport rates in gravel bed rivers". Water Resources Research 43. DOI:10.1029/2007WR006103. 
Bathurst JC. 2007. Effect of coarse surface layer on bed-load transport. Journal of Hydraulic Engineering 133(11): 1192-1205. DOI: 10.1061/(ASCE)0733-9429(2007)133:11(1192).

Bernard RS. 1993. Numerical model for depth-averaged incompressible flow. US Army Corp of Engineers, Waterways Experimental Station, Technical Report REMR-HY-11.

Church M, Hassan MA, Wolcott JF. 1998. Stabilizing self-organized structures in gravel-bed stream channels: field and experimental observations. Water Resources Research 34(11), 3169-3179. DOI: 10.1029/98WR00484.

Comiti F, Da Canal M, Surian N, Mao L, Picco L, Lenzi MA. 2011. Channel adjustments and vegetation cover dynamics in a large gravel bed river over the last 200 years. Geomorphology 125: 147-159. DOI: 10.1016/j.geomorph.2010.09.011.

Darby SE, Alabyan AD, Van de Wiel MJ. 2002. Numerical simulation of bank erosion and channel migration in meandering rivers. Water Resources Research 38. DOI: 10.1029/2001WR000602.

Ferguson RI, Parsons DR, Lane SN, Hardy RJ. 2003. Flow in meander bends with recirculation at the inner bank. Water Resources Research 39, 1322. DOI:10.1029/2003WR001965.

Formann E, Habersack HM, Schober ST. 2007. Morphodynamic river processes and techniques for assessment of channel evolution in Alpine gravel bed rivers. Geomorphology 90: 340-355. DOI: 10.1016/j.geomorph.2006.10.029.

Garcia-Martinez R, Espinoza R, Valera E, Gonzalez G. 2006. An explicit two-dimensional finite element model to simulate short- and long-term bed evolution in alluvial rivers. Journal of Hydraulic Research 44: 755-766. DOI: 10.1080/00221686.2006.9521726.

Gray JR, Laronne JB, Marr JDG. 2010. Bedload-surrogate monitoring technologies. U.S. Geological Survey Scientific Investigations Report 2010-5091, 37 pp.

Habersack H. 2001. Radio-tracking gravel particles in a large braided river in New Zealand: a field test of the stochastics theory of bed load transport proposed by Einstein. Journal of Hydrological Processes 15 (3): 377-391. DOI: 10.1002/hyp.147.

Habersack H, Piégay H. 2006. River restoration in the Alps and their surroundings: past experience and future challenges. In Gravel-Bed Rivers VI: From processes understanding to river restoration. Habersack H, Piégay H, Rinaldi M (Eds.) Elsevier. DOI: 10.1016/S0928-2025(07)11161-5.

Habersack H, Hauer C, Liedermann M, Tritthart M. 2008. Modelling and monitoring aid management of the Austrian Danube. Proceedings, Water 21; 29-31.

Habersack H, Liedermann M, Trithart M, Haimann M, Kreisler A. 2013. Innovative approaches in sediment transport monitoring and modelling. Proc. $35^{\text {th }}$ IARH World Congress, Chengdu, China.

Hassan MA, Egozi R, Parker G. 2016. Experiments on the effects of hydrograph characteristics on vertical grain sorting in gravel bed rivers. Water Resources Research vol. 42 (9), W09408, DOI: 10.1029/2005WR004707. 
Hirano M. 1971. River bed degradation with armouring. Proceedings of the Japan Society of Civil Engineering 195: 55-65. DOI: 10.2208/JSCEJ1969.1971.195_55.

Jang CL, Shimizu Y. 2005. Numerical simulation of relative wide, shallow channels with erodible banks. Journal of Hydraulic Engineering 131: 565-75.

Kaless G. 2013. Stability analysis of gravel-bed rivers: Comparison between natural rivers and disturbed rivers due to human activities. PhD Diss., Università degli Studi di Padova, Italy. Available online: http://paduaresearch.cab.unipd.it/5395/

Kaless G, Lenzi MA, Mao L. 2013. A 2D hydrodynamic-sedimentodological model for gravel bed rivers. Part I: Theory and validation. In: Proc. of the AllA Congress "Horizons in Agricultural, Forestry and Byosystems Engineering"; Viterbo (Italy), September 8-12, 2013; Journal of Agricultural Engineering vol. 44-s2, 100-107; ISSN: 2239-6268.

Keulegan GH. 1938. Laws of turbulent flow in open channels. National Bureau of Standards Research Paper RP 1151, Washington, D.C.

Kamphuis JW. 1974. Determination of sand roughness for fixed beds. Journal of Hydraulic Research 12(2): 193-203. DOI: 10.1080/00221687409499737.

Lamarre H, Mac Vicar B, Roy AG. 2005. Using passive integrated tag transponder (PIT) tags to investigated sediment transport in a gravel-bed river. Journal of Sedimentary Research 75(11): 736-741. DOI: 10.2110/jsr.2005.059.

Lamarre H, Roy AG. 2008. A field experiment on the development of sedimentary structures in a gravel-bed river. Earth Surface Process and Landforms 33: 1064-1081. DOI: 10.1002/esp.1602.

Lane SN, Richards KS, Chandler JH. 1995. Morphological estimation of the time integrated bed load transport rate. Water Resources Research 31: 761-772. DOI:10.1029/94WR01726.

Lane SN, Richards KS. 1998. High resolution, two-dimensional spatial modeling of flow processes in a multi-tread channel. Hydrological Processes 12: 1279-1298. DOI: 10.1002/(SICI)10991085(19980630)12:8<1279::AID-HYP615>3.0.CO;2-E.

Leopold LB. 1992. Sediment size that determines channel morphology. In Billi P, Hey RD, Thorne CR, Tacconi P (Eds.) Dynamics of Gravel-bed Rivers. Chichester: John Wiley and Sons; 297-311.

Li SS, Millar RG. 2007. Simulating bed-load transport in a complex gravel-bed river. Journal Hydraulic Engineering 133: 323-328. DOI:10.1061/(ASCE)0733- 9429(2007)133:3(323).

Liebault $F$, Chapuis $M$, Bellot $H$, Deschatres M. 2009. A radio frequency tracing experiment of bedload transport in a small braided mountain stream. Proceedings, EGU General Assembly 2009, Vienna, April 19-24. Geophysical Research Abstracts 11.

Liedermann M, Gerstl M, Tritthart M, Habersack H. 2010a. Monitoring artificial tracer stones at the Danube east of Vienna. Proceedings, EGU General Assembly 2010, Vienna, May 2-7. Geophysical Research Abstracts 12. 
Liedermann M, Tritthart M, Habersack H. 2010b. Bedload measurements at the large gravel river Danube, based on Eulerian and Lagrangian approaches. In Abstract Proceedings of the $7^{\text {th }}$ Gravel Bed Rivers Conference, Tadoussac, Canada, September 6-10.

Liedermann M, Tritthart M, Habersack H. 2013. Particle path characteristics at the large gravelbed river Danube: results from a tracer study and numerical modeling. Earth Surface Processes and Landforms 38(5): 512-522. DOI: 10.1002/esp.3338.

Mao L, Cooper J, Frostick L. 2011. Grain size and topographical differences between static and mobile armour layers. Earth Surface Processes and Landforms. DOI: 10.1002/esp.2156.

Mao L. 2012. The effect of hydrographs on bed load transport and bed sediment spatial arrangement. Journal of Geophysical Research: Earth Surface 117: F03024. DOI:10.1029/2012JF002428.

Mao L, Picco L, Lenzi MA, Surian N. Submitted. Bedload transport estimate in large gravel-bed rivers using the virtual velocity approach. Journal of Geophysical Research: Earth Surface.

McLean DG, Church M. 1999. Sediment transport along lower Fraser River. 2. Estimates based on the long-term gravel budget. Water Resourses Research 35(8): 2549-2559. DOI:10.1029/1999WR900102.

Monteith H, Pender G. 2005. Flume investigations into the influence of shear stress history on a graded sediment bed. Water Resources Research 41: W12401. DOI:10.1029/2005WR004297.

Moretto J, Rigon E, Mao L, Delai F, Picco L, Lenzi MA. 2014a. Short-term geomorphic analysis in a disturbed fluvial environment by fusion of LiDAR, colour bathymetry and dGPS surveys. Catena 122: 180-195. DOI:10.1016/j.catena.2014.06.023.

Moretto J, Rigon E, Mao L, Picco L, Delai F, Lenzi MA. 2014b. Channel adjustments and vegetation cover dynamics in the Brenta River (Italy) over the last 30 years. River Research and Applications 30: 719-732. DOI: 10.1002/rra.2676.

Nagata N, Hosoda T, Muramato Y. 2000. Numerical analysis of river channel processes with bank erosion. Journal Hydraulic Engineering 126: 243-252. DOI: 10.1061/(ASCE)07339429(2000)126:4(243).

Neill CR. 1987. Sediment balance considerations linking long-term transport and channel processes. In: Sediment Transport in Gravel-Bed Rivers, CR Thorne, JC Bathurst, RD Hey (eds.). 225-40. Chichester, UK/New York: Wiley. 995 pp.

Paphitis D, Collins MB. 2005. Sand grain threshold, in relation to bed 'stress history': an experimental study. Sedimentology 52: 827-838. DOI: 10.1111/j.1365-3091.2005.00710.x.

Parker G. 1990. Surface-based bedload transport relation for gravel rivers. Journal Hydraulic Research 28: 417-436. DOI: 10.1080/00221689009499058. 
Parker G, Klingeman PC. 1982. On why gravel bed rivers are paved. Water Resources Research 18(5): 1409-1423. DOI: 10.1029/WR018i005p01409.

Parker G, Sutherland AJ. 1990. Fluvial armor. Journal Hydraulic Research 28: 529-544. DOI: 10.1080/00221689009499044.

Parker G, Hassan M, Wilcock P. 2006. Adjustment of the bed surface size distribution of gravelbed rivers in response to cycled hydrographs. In Gravel-Bed Rivers VI: From processes understanding to river restoration. Habersack $\mathrm{H}$, Piégay $\mathrm{H}$, Rinaldi M (Eds.). Amsterdam, Elsevier Science, 241-285.

Recking A, Liébault F, Peteuil C, Jolimet T. 2012. Testing bedload transport equations with consideration of time scales. Earth Surface Processes and Landforms 37(7): 774-789. DOI:10.1002/esp.3213.

Rennie CD, Millar RG. 2004. Measurement of the spatial distribution of fluvial bed load transport velocity in both sand and gravel. Earth Surface Processes and Landforms 29: 1173-1193. DOI: 10.1002/esp.1074.

Rice S, Church M. 1996. Sampling surficial fluvial gravels: the precision of size distribution percentile estimates. Journal of Sedimentary Research 66(3): 654-665.

Rigon E, Moretto J, Mao L, Picco L, Delai F, Ravazzolo D, Lenzi MA, Kaless G. 2012. Thirty years of vegetation cover dynamics and planform changes in the Brenta River (Italy): implications for channel recovery. IAHS PubI. 356: 178-186. ISSN: 0144-7815.

Rinaldi M, Wyzga B, Surian N. 2005. Sediment mining in alluvial channels: physical effects and management perspectives. River Research Applications 21: 805-828. DOI: 10.1002/rra.884.

Rodriguez JF, Bombardelli FA, García MH, Frothingham KM, Rhoads BL, Abad JD. 2004. Highresolution numerical simulation of flow through a highly sinuously river reach. Water Resources Management 18: 177-199. DOI: 10.1023/B:WARM.0000043137.52125.a0.

Rozovskii IL. 1961. Flow of water in bends of open channels. Translated by Y. Prushansky, Jerusalem Program Sci. Translation.

Shamutz M, Aufleger M. 2002. Gravel river widening by bank erosion: theory and results of physical and numerical modelling. Proceedings, River flow 2002, International Conference on Fluvial Hydraulics, Louvain-la-Neuve, Belgium, Vol 1: 639-649.

Schmautz M. 2003. Eigendynamische Aufweitung in einer geraden Gewässerstrecke- Entwicklung und Untersuchungen an einem numerischen Model. Berichte des Lehrstuhls und der Versuchsanstalt für Wasserbau und Wasserwirtschaft der TU München, Nr.96.

Schmautz M. 2004. Gravel river widening by bank erosion in a straight stretch of river investigations on a numerical model. Proceedings, River Flow 2004 - International Conference on Fluvial hydraulics, Naples, Italy. 99-107 
Surian N, Rinaldi M. 2003. Morphological response to river engineering and management in alluvial channels in Italy. Geomorphology 50: 307-326. DOI:10.1016/S0169-555X(02)00219-2.

Surian N, Cisotto A. 2007. Channel adjustments, bedload transport and sediment sources in a gravel-bed river, Brenta River, Italy. Earth Surface Processes and Landforms 32, 1641-1656. DOI: 10.1002/esp.1591.

Tritthart M, Gutknecht D. 2007a. Three-dimensional simulation of free-surface flows using polyhedral finite volumes. Engineering Applications of Computational Fluid Mechanics 1: 1-14.

Tritthart M, Gutknecht D. 2007b. 3D computation of flood processes in sharp river bends. Water Management 160: 233-247. DOI: 10.1680/wama.2007.160.4.233.

Tritthart M, Liedermann M, Habersack H. 2009. Modelling spatio-temporal flow characteristics in groyne fields. River Research and Applications 25: 62-81. DOI: 10.1002/rra.1169.

Tritthart M, Schober B, Habersack H. 2011a. Non-uniformity and layering in sediment transport modelling 1: flume simulations. Journal of Hydraulic Research 49(3): 325-334. DOI: 10.1080/00221686.2011.583528.

Tritthart M, Liedermann M, Schober B, Habersack H. 2011b. Non-uniformity and layering in sediment transport modelling 2: river application. Journal of Hydraulic Research 49(3): 335-344. DOI: 10.1080/00221686.2011.583528.

Wheaton JM, Brasington J, Darby SE, Sear DA. 2010. Accounting for uncertainty in DEMs from repeat topographic surveys: improved sediment budgets. Earth Surface Processes and Landforms 35: 136-156. DOI: 10.1002/esp.1886.

Wilcock PR. 1997. The components of fractional transport rate. Water Resources Research 33(1): 247-258. DOI: 10.1029/96WR02666.

Wilcock PR. 2001. Toward a practical method for estimating sediment-transport rates in gravelbed rivers. Earth Surface Processes and Landforms 26: 1395-1408. DOI: 10.1002/esp.301.

Wilcock PR, Kenworthy ST, Crowe J. 2001. Experimental study of the transport of mixed sand and gravel. Water Resources Research 37(12): 3349-3358. DOI: 10.1029/2001WR000683.

Wilcock PR, Crowe JC. 2003. Surface-based transport model for mixed-size sediment. Journal Hydraulic Engineering 129(2): 120-128. DOI: 10.1061/(ASCE)0733-9429(2003)129:2(120).

Wong M, Parker G. 2003. Reanalysis and correction of bed-load relation of Meyer-Peter and Müller using their own database. Journal of Hydraulic Engineering 132(11). DOI: 10.1061/(ASCE)0733-9429(2006)132:11(1159).

Wu W. 2007. Computational River Dynamics. London, Taylor and Francis Group. ISBN: 978-0-41544961-8. 
Wu W, Rodi W, Thomas W. 2000. 3D numerical modelling of flow and sediment transport in open channels. Journal Hydraulic Engineering 126: 183-188. DOI: 10.1061//(ASCE)07339429(2000)126:1(4).

Wu W, Wang SSY. 2006. Formulas for sediment porosity and settling velocity. Journal Hydraulic Engineering 132(8): 858-862. DOI: 10.1061/(ASCE)0733-9429(2006)132:8(858).

Zhu J. 1991. A low-diffusive and oscillation-free convection scheme. Communications in Applied Numerical Methods 7: 225-232.

Ziliani L, Surian N. 2012. Evolutionary trajectory of channel morphology and controlling factors in a large gravel-bed river. Geomorphology 173-174: 104-117. DOI:10.1016/j.geomorph.2012.06.001.

\section{TABLES}

Table 1. Comparison between predicted and observed grain size distributions (GSD) of outlet sediment transport and final surface material. Values in brackets are the standard deviations of measurements.

\begin{tabular}{ccccr} 
& \multicolumn{2}{c}{ Transported GSD } & \multicolumn{2}{c}{ Bed surface GSD } \\
& Pred & Obs & Pred & \multicolumn{1}{c}{ Obs } \\
\hline D16 $(\mathrm{mm})$ & 3.0 & $3.6(0.6)$ & 4.5 & $4.1(0.4)$ \\
D50 $(\mathrm{mm})$ & 5.4 & $5.6(0.7)$ & 7.5 & $8.1(1.5)$ \\
D84 $(\mathrm{mm})$ & 8.0 & $10.3(0.8)$ & 16.1 & $17.7(2.5)$ \\
\hline
\end{tabular}

Table 2. Analysis of mass balance, sediment supply and outlet within the sub-reach between cross sections located at $x=300 \mathrm{~m}$ and $\mathrm{x}=1250 \mathrm{~m}$. The value in brackets is the uncertainty in measurements. $(*)$ interpolated values from simulations Run 3 and Run 4.

\begin{tabular}{cccccc} 
& & \multicolumn{4}{c}{ Simulations } \\
\cline { 3 - 6 } & Observed & Run 1 & Run 2 & Run 3 & Run 4 \\
\hline Input & $68,940(*)$ & 180,641 & 133,343 & 103,069 & 79,388 \\
Output & $108,517(*)$ & 163,114 & 135,877 & 119,222 & 111,647 \\
Mass Balance & $-39,577(11,407)$ & 17,527 & $-2,626$ & $-16,285$ & $-32,446$ \\
\hline
\end{tabular}


Figure captions

Figure 1. Comparison of predicted and observed total sediment transport (error bands represent the standard deviation).

Figure 2. Comparison of predicted and observed outgoing sediment transport. Model sensitivity has been assessed by changing the downstream water surface elevation (see text).

Figure 3. Measured fractional transport rates divided by the grain size frequency in the bed surface. At the beginning of the experiment full transport took place while by the end, transport was partial. The figure also includes fractional ratios predicted with Wilcock and Crowe's (2003) sediment transport model.

Figure 4. Comparison between predicted and observed bed elevation. The armour ratio of the surface layer is also included for Run 1.

Figure 5. Comparison between predicted and observed channel width (width is measured at half the depth of the channel).

Figure 6. Location and aerial image of the study reach. On the right: location of the lowest part of the Brenta River that flows across the Venetian plain (Veneto Region, Italy); Barziza is the gauging station located some kilometers upstream of the study reach. On the right: areal image of the study reach near Nove village, with indication of stations along the reach. The flow is from top to bottom.

Figure 7. Comparison between bankfull levels measured in the field and predicted by the model using the relative roughness $\mathrm{ks} / \mathrm{D}_{90}=2$.

Figure 8. Sequence of Difference of DTMs (DoD) calculated by the model when the sediment supply is reduced (from left to right). The sediment supply is referred relative to input of Run 1 (simulation with recirculation of sediments). The last figure (right) corresponds to the DoD as resulting from the DTMs measured in the field. The flow is from top to bottom.

Figure 9. Mass balance at each cross section along the study reach. The balance is calculated as the difference of DTMS corrected with the porosity of the bed material. Two uncertainty bands have been included for field observations.

Figure 10. Downstream difference in DoD that highlights the coincidence in all the situations (runs and observation) of the same pattern of variation in DoD.

Figure 11. Sediment transport rate as calculated by the model with Run 4. Sediment transport models derived from researches conducted in gravel-bed rivers have been included (Barry et al., 2007 and Bathurst, 2007) 
Figure 1 Comparison of predicted and observed total sediment transport (error bands represent the standard deviation). $104 \times 77 \mathrm{~mm}(300 \times 300 \mathrm{DPI})$ 
1

2

3

4

5

6

7

8

9

10

11

12

13

14

15

16

17

18

19

20

21

22

23

24

25

26

27

28

29

30

31

32

33

34

35

36

37

38

39

40

41

42

43

44

45

46

47

48

49

50

51

52

53

54

55

56

57

58

59

60

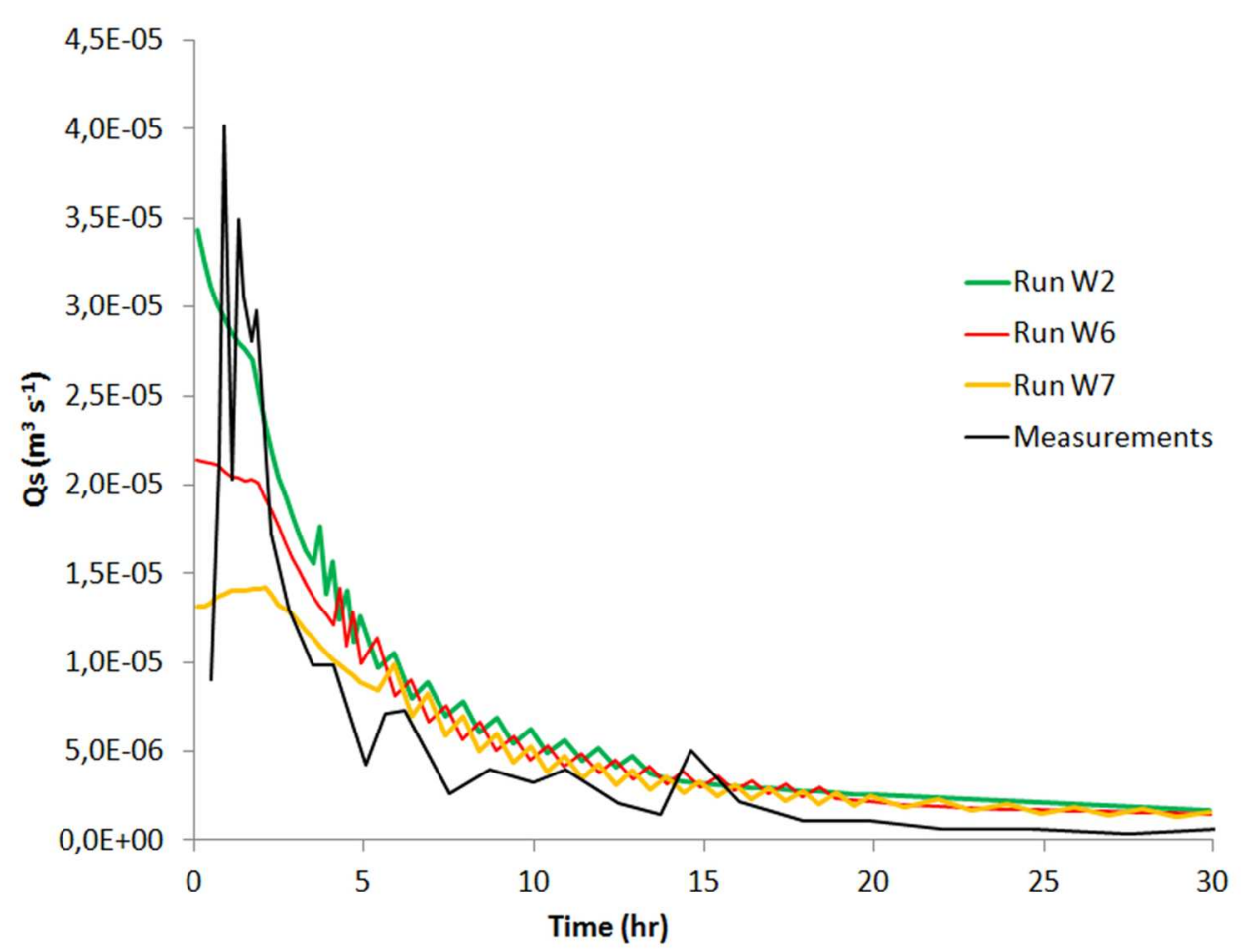

Comparison of predicted and observed outgoing sediment transport. Model sensitivity has been assessed by changing the downstream water surface elevation (see text) $105 \times 79 \mathrm{~mm}$ (300 x 300 DPI) 


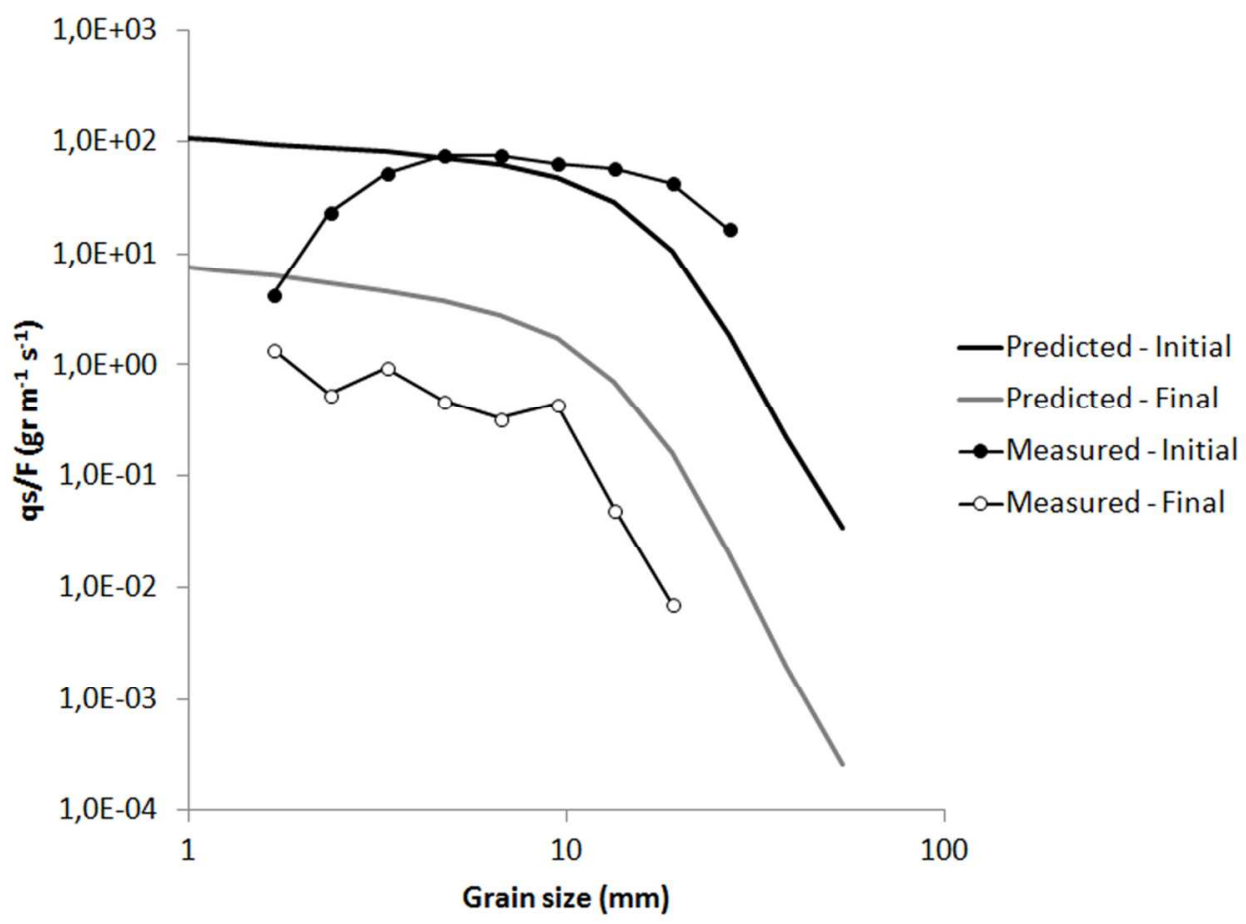

Figure 3 Measured fractional transport rates divided by the grain size frequency in the bed surface. At the beginning of the experiment full transport took place while by the end, transport was partial. The figure also includes fractional ratios predicted with Wilcock and Crowe's (2003) sediment transport model. $105 \times 78 \mathrm{~mm}$ (300 x 300 DPI) 
1

2

3

4

5

6

7

8

9

10

11

12

13

14

15

16

17

18

19

20

21

22

23

24

25

26

27

28

29

30

31

32

33

34

35

36

37

38

39

40

41

42

43

44

45

46

47

48

49

50

51

52

53

54

55

56

57

58

59

60

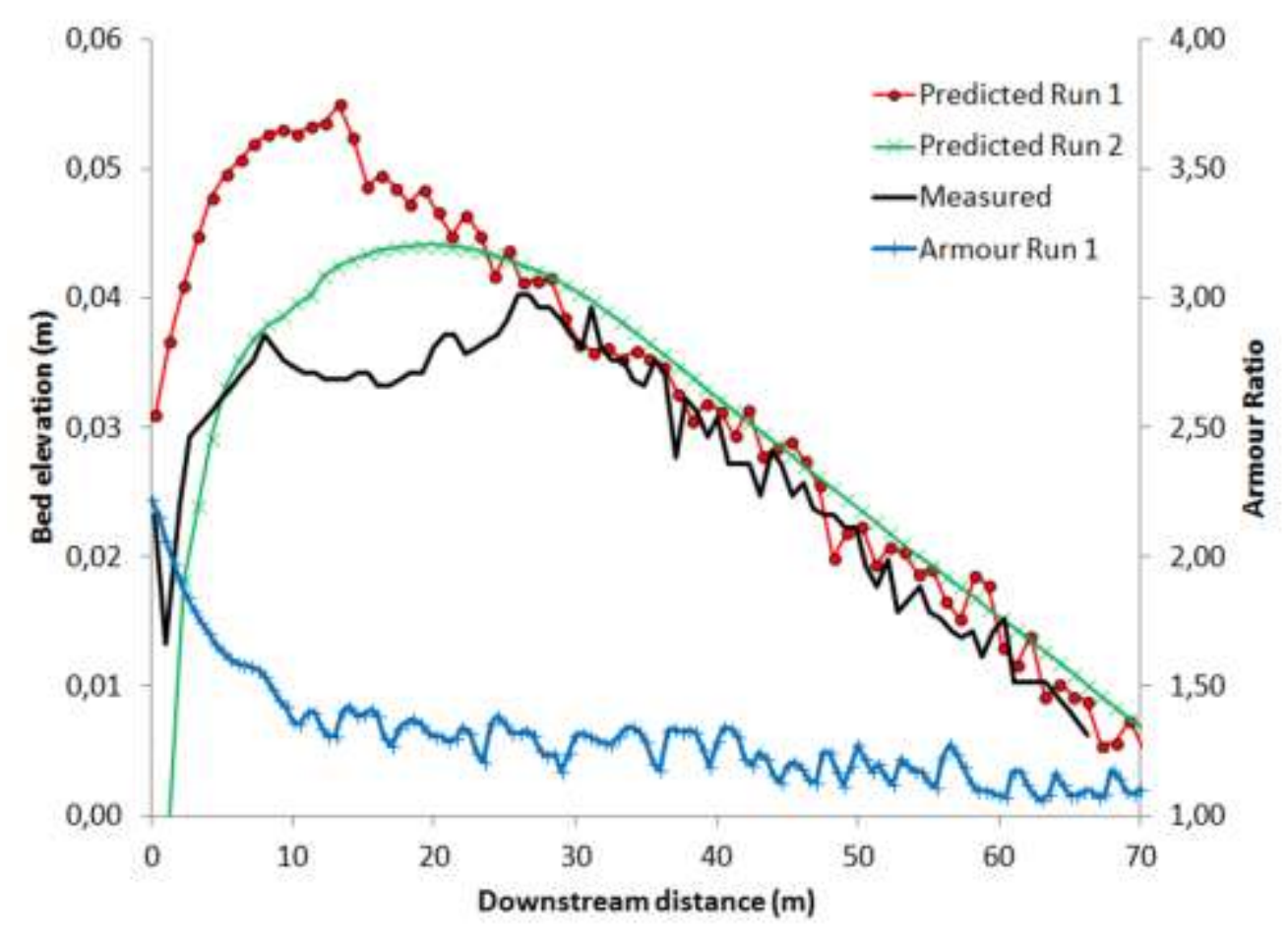

Figure 4 Comparison between predicted and observed bed elevation. The armour ratio of the surface layer is also included for Run 1. $104 \times 78 \mathrm{~mm}(300 \times 300$ DPI) 


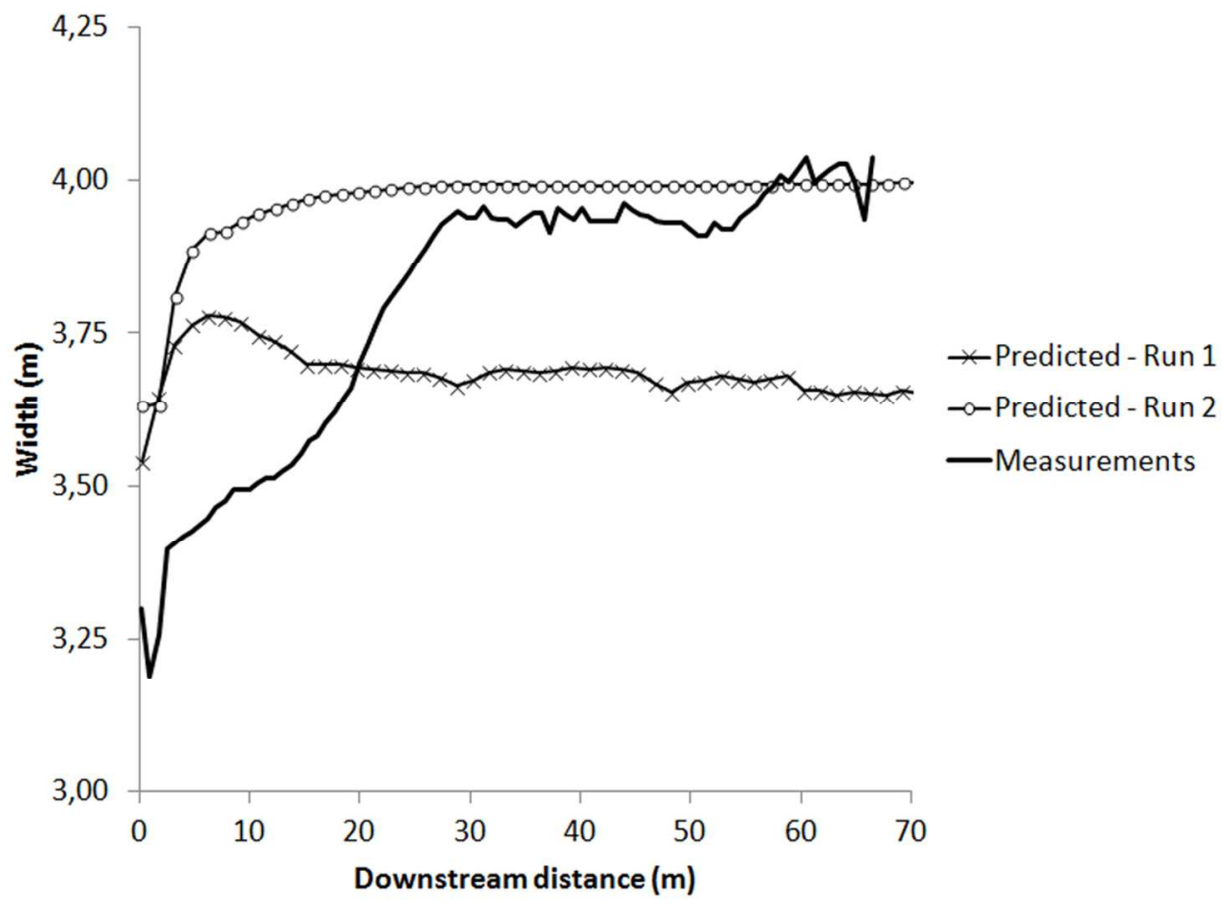

Figure 5 Comparison between predicted and observed channel width (width is measured at half the depth of the channel). $104 \times 77 \mathrm{~mm}(300 \times 300 \mathrm{DPI})$ 
- Location and aerial image of the study reach. On the right: location of the lowest part of the Brenta River that flows across the Venetian plain (Veneto Region, Italy); Barziza is the gauging station located some kilometers upstream of the study reach. On the right: areal image of the study reach near Nove village, with indication of stations along the reach. The flow is from top to bottom. $26 \times 27 \mathrm{~mm}(300 \times 300 \mathrm{DPI})$ 
Location and aerial image of the study reach. On the right: location of the lowest part of the Brenta River that flows across the Venetian plain (Veneto Region, Italy); Barziza is the gauging station located some kilometers upstream of the study reach. On the right: areal image of the study reach near Nove village, with indication of stations along the reach. The flow is from top to bottom. $74 \times 210 \mathrm{~mm}(300 \times 300$ DPI $)$ 
1

2

3

4

5

6

7

8

9

10

11

12

13

14

15

16

17

18

19

20

21

22

23

24

25

26

27

28

29

30

31

32

33

34

35

36

37

38

39

40

41

42

43

44

45

46

47

48

49

50

51

52

53

54

55

56

57

58

59

60

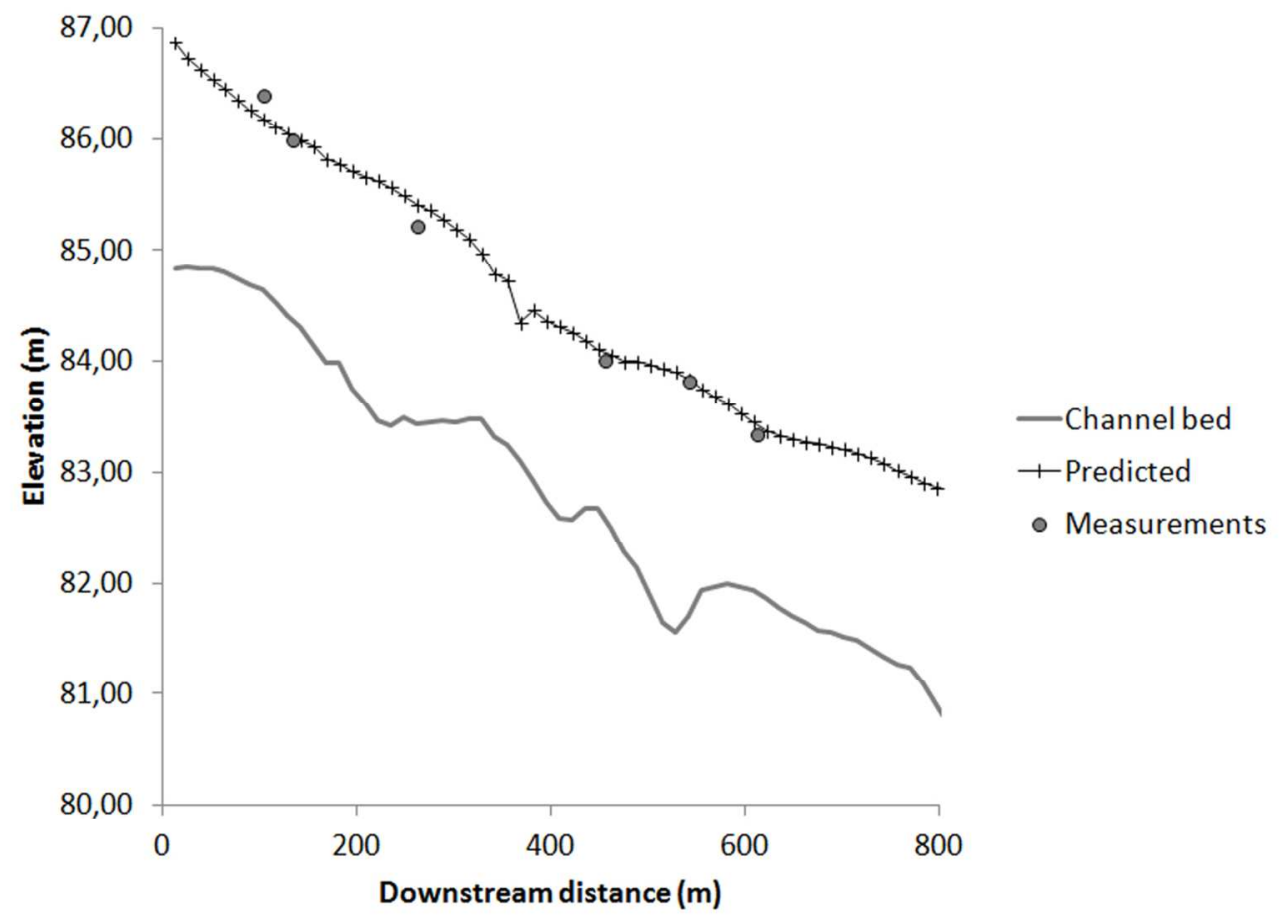

Figure 7 Comparison between bankfull levels measured in the field and predicted by the model using the relative roughness $\mathrm{ks} / \mathrm{D} 90=2$. $104 \times 77 \mathrm{~mm}(300 \times 300$ DPI $)$ 


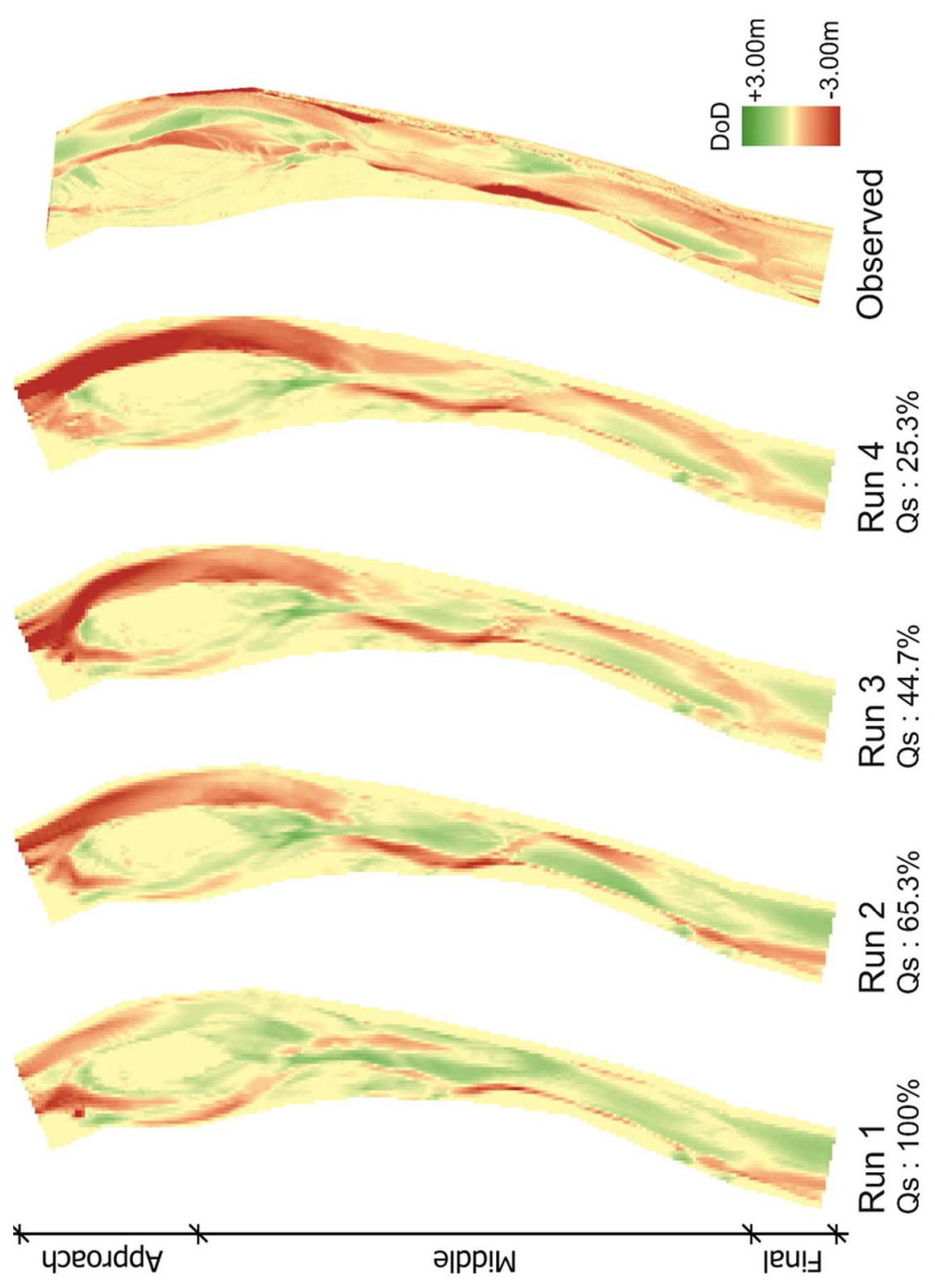

Figure 8 Sequence of Difference of DTMs (DoD) calculated by the model when the sediment supply is reduced (from left to right). The sediment supply is referred relative to input of Run 1 (simulation with recirculation of sediments). The last figure (right) corresponds to the DoD as resulting from the DTMs measured in the field. The flow is from top to bottom.

$78 \times 109 \mathrm{~mm}(300 \times 300$ DPI) 
Figure 9 Mass balance at each cross section along the study reach. The balance is calculated as the difference of DTMS corrected with the porosity of the bed material. Two uncertainty bands have been included for field observations. $106 \times 81 \mathrm{~mm}(300 \times 300 \mathrm{DPI})$ 


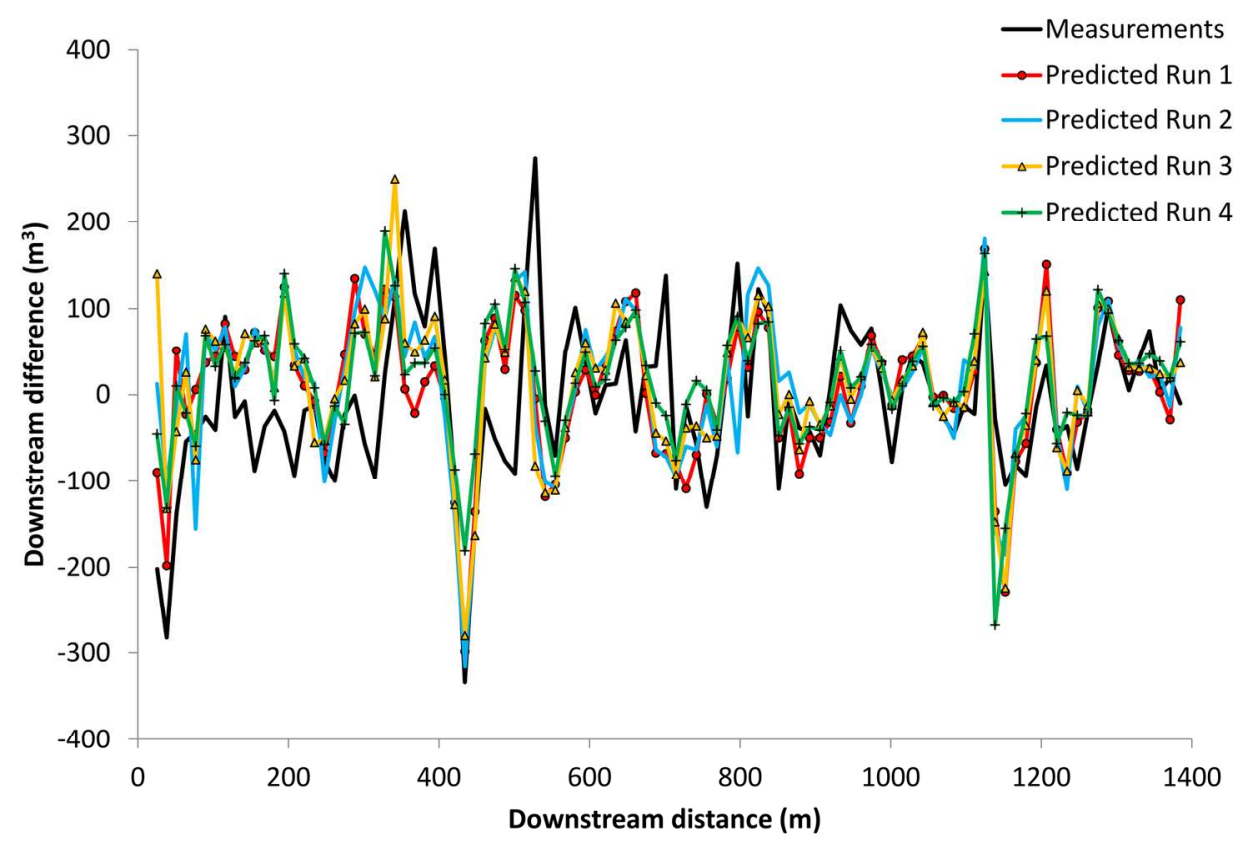

Figure 10 Downstream difference in DoD that highlights the coincidence in all the situations (runs and observation) of the same pattern of variation in DoD. $165 \times 114 \mathrm{~mm}(300 \times 300$ DPI $)$ 
Figure 11 Sediment transport rate as calculated by the model with Run 4 . Sediment transport models derived from researches conducted in gravel-bed rivers have been included (Barry et al., 2007 and Bathurst, 2007) $104 \times 78 \mathrm{~mm}(300 \times 300 \mathrm{DPI})$ 